\title{
Paternalistic Pension Policy: Psychological Evidence and Economic Theory
}

\author{
Deborah M. Weiss † \\ "[W]e can't always have what we want. Sometimes we have to \\ have what's good for us."
}

Margaret Thatcher

Left to their own devices, many people will not save enough for their old age. This hard truth about human behavior has led American government to make a long and expensive commitment to retirement security programs. Indeed, Congress has made retirement security the most expensive commitment on the American public policy agenda. Of the two main components of this policy, one, Social Security, is by far the most costly domestic program. The other, the system of tax subsidies to employer pensions, is the federal government's largest tax expenditure. ${ }^{2}$ With the great expenditures on these programs, Congress has set out to guarantee that even the most profligate young worker will have something to retire on.

These massive programs, however, have not entirely achieved their goal. As a host of critics have pointed out, pension coverage remains distressingly spotty and inequitable. ${ }^{3}$ The highest subsi-

$\dagger$ Assistant Professor of Law, Stanford University. Previous drafts of this Article have received more kind attention than they deserved from Janet Cooper Alexander, Joe Bankman, Bill Baxter, Richard Craswell, Barbara Fried, Ron Gilson, Mark Kelman, Lewis Kornhauser, Bob Mnookin, Mitch Polinsky, Roberta Romano, Susan Rose-Ackerman, David Rosenhan, Bill Simon, Cass Sunstein, and James Whitman.

1 Quoted in Bernadine Morris, British Fashion Rises and Shines, NY Times B14 (Mar 20, 1984).

3 Budget of the United States Government, Fiscal Year 1991, H Doc 101-122, 101st Cong, 2d Sess A-737 (GPO, 1990). See notes 10-15 and accompanying text.

3 See, for example, Nancy J. Altman, Rethinking Retirement Income Policies: Nondiscrimination, Integration, and the Quest for Worker Security, 42 Tax L Rev 435, 501 (1987); Michael Boskin and John B. Shoven, Concepts and Measures of Earning Replacement During Retirement, 1987 Issues in Pension Econ 113, 125; Martin Feldstein, The Social Security Explosion, 81 Pub Interest 94, 104-05 (1985); Michael J. Boskin, Too Many Promises: The Uncertain Future of Social Security 2-3, 102-04 (Dow Jones-Irwin, 1986); Michael Boskin and John B. Shoven, Poverty Among the Elderly: Where Are the Holes in the Safety Net?, in Zvi Bodie, John B. Shoven, and David A. Wise, Pensions in the U.S. Economy (Chicago, 1988); Richard B. Freeman, Unions, Pensions, and Union Pension 
dies are paid to affluent consumers who need pensions the least, while those most in need often have no pension coverage at all. More than a half century of effort since the New Deal seems to have achieved only limited success, and reform proposals abound. ${ }^{4}$

They abound, in particular, among economists. Some of the nation's most prominent economists have tried their hands at refashioning American pension policy. ${ }^{\circ}$ Yet policymakers have generally ignored the economists' recommendations. There is, of course, nothing unusual in this: Policymakers often have little use for policy-thinkers. Nevertheless, it is particularly unsurprising that policymakers should ignore the recommendations of economists in the pension arena, for pension policy is paternalistic, and paternalism is something economists have a great deal of difficulty understanding.

Paternalism presumes that people are unable to understand their own best interest and require the protection of a benevolent state. In the pension context, paternalism supposes that young people may not save enough unless forced or encouraged to do so-supposes, that is, the hard truth with which I began: that many people, left to their own devices, will not save enough for their old age. Such paternalistic concerns are difficult to reconcile with the assumptions that underlie economic analysis, for economists presume that each individual knows what is best for himself. Individuals, economists assume, rationally examine the opportunities available to them, and choose the one they value most highly. This conception of rational choice suggests that individual choices maximize individual welfare, a conclusion known as consumer sov-

Funds, in David A. Wise, Pensions, Labor, and Individual Choice 89, 98-99 (Chicago, 1985). See notes 31-38 and accompanying text.

- Richard A. Ippolito, Pensions, Economics and Public Policy 207 (Dow Jones-Irwin, 1986); Richard A. Ippolito, Pensions and Economics: Towards an Efficient Retirement Policy, in Jack L. VanDerhei, ed, Search for a National Retirement Income Policy 33, 35-37 (Pension Research Council, 1987); HR Rep No 3972, 101st Cong, 2d Sess, §§ 201, 202 (Feb 12, 1990); S 1682, 101st Cong, 2d Sess (Sep 27, 1989), in 135 Cong Rec S12010 (daily ed, Sep $27,1989)$ (housing and education proposal); Paul A. Samuelson, Optimal Social Security in a Life-Cycle Growth Model, 26 Intl Econ Rev 539 (1975); Boskin, Too Many Promises at 100 (cited in note 3); S 2026, 101st Cong, 2d Sess (Jan 25, 1990), in 136 Cong Rec S 412 (Jan 25,1990 ) (Symms); HR 3083, \& 2, 101st Cong, 1st Sess (Aug 2, 1989), in 135 Cong Rec H4946 (Aug 2, 1989) (Porter); David Boaz, Privatize Social Security, NY Times A27 (Mar 21, 1990); Anthony E. Scoville, Security for Social Security, NY Times A23 (Jul 23, 1982); Altman, 42 Tax L Rev at 456-500 (cited in note 3); Emily S. Andrews, The Changing Profile of Pensions in America 165-69 (Employee Benefit Research Institute, 1985); Michael J. Graetz, The Troubled Marriage of Retirement Security and Tax Policies, $135 \mathrm{U} \mathrm{Pa} \mathrm{L}$ Rev 851, 906-08 (1987). See notes 53-67, 83-88 and accompanying text.

'See, for example, Boskin, Too Many Promises at 100-04 (cited in note 3). 
ereignty. With such assumptions, economists find it difficult to explain what it means for a household to have saved too little: the analytic framework of economics implies that no paternalistic intervention can improve on the household's own actions. How then can economists hope to advise Congress on this most paternalistic of policies?

To be sure, some economists have been reluctant to endorse the conclusion that all individuals make the best possible savings decisions. ${ }^{6}$ But even with the best intentions, they have had difficulty modifying the economic model to explain how or why individuals make a less-than-ideal choice. Even those economists who are in principle willing to abandon their ingrained theoretical attachment to the assumptions of the economic theory of human behavior cannot do so without an analytic alternative. They need to show that individuals make mistakes and, more significantly, that those mistakes can be analyzed. They need to show that individuals err systematically in ways that can be exploited by paternalistic policymakers.

The purpose of this Article is to show that individuals do err systematically, and that an analytic paternalistic pension policy can be founded on the phenomenon of time inconsistency. ${ }^{7}$ There is a growing body of empirical evidence, gathered primarily by psychologists, that suggests that over time consumer choice is not always consistent. ${ }^{8}$ This evidence of inconsistency offers a founda-

\footnotetext{
- See notes 90-96 and accompanying text.

'See, for example, Guillermo Calvo, Some Notes on Time Inconsistency and Rawls' Maximin Criterion, 45 Rev Econ Stud 97 (1978).

- Douglas J. Navarick, Negative Reinforcement and Choice in Humans, 13 Learning and Motivation 361 (1982); Jay V. Solnick, et al, An Experimental Analysis of Impulsivity and Impulse Control in Humans, 11 Learning and Motivation 61 (1980); Andrew Millar and Douglas J. Navarick, Self-Control and Choice in Humans: Effects of Video Game Playing as a Positive Reinforcer, 15 Learning and Motivation 203 (1984); George Ainslie and Varda Haendel, The Motives of the Will, in Edward Gottheil, et al, eds, Etiologic Aspects of Drug and Alcohol Abuse 119 (Charles C. Thomas, 1983); Uri Benzion, Amnon Rapoport, and Joseph Yagil, Discount Rates Inferred from Decisions: An Experimental Study, $35 \mathrm{Mgmt}$ Sci 270 (1989); Richard Thaler, Some Empirical Evidence on Dynamic Inconsistency, 8 Econ Letters 201 (1981); George Ainslie, Specious Reward: A Behavioral Theory of Impulsiveness and Impulse Control, 82 Psych Bull 463 (1975); A. W. Logue, Research on Self-Control: An Integrating Framework, 11 Behavioral and Brain Sciences 665 (1988); Howard Rachlin and Leonard Green, Commitment, Choice and Self-Control, $17 \mathrm{~J}$ Exprmtl Analysis Behavior 15 (1972); Walter Mischel, Ebbe B. Ebbesen, and Antonette R. Zeiss, Cognitive and Attentional Mechanisms in Delay of Gratification, 21 J Personality and Soc Psych 204 (1972); George F. Loewenstein, Frames of Mind in Intertemporal Choice, 34 Mgmt Sci 200 (1988). Attempts at theoretical analysis include George F. Loewenstein, Anticipation and the Valuation of Delayed Consumption, 97 Econ J 666 (1987); Thomas Schelling, The Intimate Contest for Self-Command, in Thomas Schelling, Choice and Consequence 57 (Harvard, 1984). See notes 103-05, 117-19 and accompanying text.
} 
tion for a methodical analysis of paternalistic savings policies, an analysis that will aid in the creation of more satisfactory retirement security programs. Drawing on this psychological evidence, then, I argue that an understanding of the mechanism by which consumer sovereignty breaks down can help in designing a cost effective paternalistic pension policy. In particular, this Article will identify two different types of breakdowns in consumer sovereignty. On the one hand, preference change may result from the mere passage of time; on the other hand, preferences may change because of features of the situation in which the individual finds himself.

An individual whose preferences change over time is in many respects like a rational consumer: he makes decisions on the margin, and although his choices do not always produce optimal results, they can be manipulated with conventional economic tools such as tax subsidies. In contrast, the behavior of an individual whose preferences change from situation to situation does not conform to the fundamental economic principle of marginalism. That behavior cannot be systematically changed by marginal subsidies. Instead, such an individual can be induced to save by various techniques that would have no effect on rational agents or on individuals with time-dependent preference change. Finally, individuals with either type of preference change have one trait in common: the savings of both groups can be manipulated by precommitment devices which would not affect the behavior of rational individuals.

Section I of this Article examines how current American law implements paternalistic pension policy. Section II evaluates the methodological obstacles to applying standard economic savings theory to paternalistic policy. It also describes neoclassical arguments that justify a certain degree of state interventionism but do not adequately explain the need for paternalism. Section III examines non-neoclassical criticisms of the pension system. I argue that these criticisms make important points but fail to show any behavioral basis for formulating a paternalistic pension policy. Section IV examines a modified neoclassical theory. I argue that this approach fails to resolve the fundamental methodological puzzle that prevents the application of neoclassical methods to paternalistic policy. Section V turns to experimental psychology. This section details the empirical evidence of inconsistency in choice over time. It then explores the two most likely causes of this inconsis- 
tency-time-inconsistent preferences and situational preference change-and argues that the existence of either type of preference change justifies, in some instances, paternalistic policy intervention. Section VI examines the implications of inconsistent preferences for the choice among policy tools and offers concrete proposals.

\section{America's Paternalistic Savings Policy}

Paternalism has long been held in disrepute, and overt admissions of paternalistic policy goals are seldom heard in the public arena. Nevertheless, everyone who is subject to Social Security withholding knows that America has a policy of forced savings and must suspect that that policy has a paternalistic objective. A close examination of the design of the present regime of pension policies shows that regime is deeply molded by paternalistic concerns.

The United States attempts to provide retirement income security through two programs: Social Security and the system of tax subsidies for retirement savings. Both of these mechanisms display Congress's desire to protect people from the consequences of their own actions by restricting individual choice.

The design of Social Security most clearly shows Congress's preference for policies that raise savings through restrictions on individual choice. Social Security comprises about fifty-four percent of the average household's post-retirement income. ${ }^{9}$ With 1991 Social Security payments estimated to be $\$ 235$ billion, ${ }^{10}$ it is by far the most expensive domestic program. Participation in Social Security is compulsory. Thus, for the individual contributor, the Social Security system is just like forced savings: individuals are required to give up consumption now in return for more consumption later. ${ }^{11}$

- Boskin and Shoven, 1987 Issues in Pension Econ at 124 (cited in note 3).

30 Budget of the United States Government Fiscal Year 1991 at A-737 (cited in note 2).

11 From a public perspective, Social Security is not a form of savings. If Social Security payroll taxes were invested in a trust fund, the trust would contribute to national savings. The trust would loan invested funds for use as capital investment. As individuals retired, the government would finance their Social Security checks from the return on the fund, or through partial liquidation of the fund. If the present workforce made no further contributions, the trust would pay at least partial annuities from the return on the trust fund investments. Instead, under the present unfunded system, the Social Security administration pays out the proceeds of the payroll tax to current retirees rather than investing them. In general, if tax payments were to cease, annuities would also. (This is subject to a qualification: The fund at present runs a temporary surplus because of the large size of the current working cohort.) Social Security is therefore not a form of savings, since at present the trust funds are not invested in the capital stock. Feldstein, The Social Security Explosion, 81 Pub In- 
Though Social Security is the most obviously paternalistic program, it is by no means the only one. The system of tax incentives also has a paternalistic character, though of a more subtle kind. Unlike Social Security, the tax system does not require individuals to save. Rather, it encourages savings through subsidies. But existing subsidies are intended to serve a paternalistic objective. As we will see shortly, the Internal Revenue Code provides the highest ceilings on tax deductions to those pension programs that leave the least room for individual choice regarding savings levels.

The system of tax incentives breaks down into two basic programs: subsidization of employer-sponsored plans ${ }^{12}$ and subsidization of Individual Retirement Accounts. ${ }^{13}$ This tax-incentive system is more limited than Social Security, with private pensions accounting for fifteen percent of average post-retirement income. ${ }^{14}$ Still, it is far from negligible: the tax exemption for employersponsored pensions is the largest single tax preference in the Internal Revenue Code, costing an estimated $\$ 46.9$ billion in lost revenues in $1991 . .^{15}$ Like Social Security, this costly system disfavors individual choice. It gives the most generous deductions to nonelective employer-sponsored pension plans, in which the employee is not permitted to choose between wages and pension contributions. ${ }^{16}$ Such non-elective plans must cover all members of a predetermined group-individual employees of participating employers are forced to contribute to their own retirement savings. Non-elective plans receive very favorable tax treatment. Both the employer contributions and the subsequent interest on these contributions are deductible, and these deductions can be taken on contributions

terest at 104-05 (cited in note 3); Boskin, Too Many Promises at 7-11 (cited in note 3); Martin Feldstein, Social Security and Saving: The Extended Life Cycle Theory, 66(2) Amer Econ Rev 77, 85 (1976).

12 Internal Revenue Code (IRC), 26 USC \& 401(a) (1991).

1s IRC \& 408. Keogh plans, which are for self-employed individuals, belong in some sense to both types.

14 Boskin and Shoven, 1987 Issues in Pension Econ at 124 (cited in note 3).

15 Budget of the United States Government, Fiscal Year 1991 at A-73 (cited in note 2). For 1991, the Office of Management and Budget projects that tax preferences for IRAs and Keoghs will cost the treasury $\$ 6.2$ and $\$ 1.6$ billion respectively. Id.

${ }^{18}$ IRC $\S$ 404(a)(1), 404(a)(2), 404(a)(3) (employer deduction); IRC § 402(a)(1) (employee); IRC $\$ \S 501(\mathrm{a}), 501(\mathrm{c})(24)$. In the absence of such provisions, employer contributions to such plans, would, under usual tax principles, constitute a deductible business expense for the employer, and current income to the employee; the appreciation on any investment would be taxable as it accrued. 
of up to $\$ 30,000$ per year ${ }^{17}$ or until a pension annuity of $\$ 90,000$ per year is reached..$^{18}$

The contrast with voluntary employee contributions to employer-sponsored plans is striking. Congress is far less generous in subsidizing voluntary contributions. Such contributions may take either of two forms, both of which receive a smaller subsidy than that accorded to non-elective plans. First, some voluntary contributions supplement employer contributions to the main plan. Individuals can only make these contributions from after-tax wage income-substantially disfavored treatment. ${ }^{19}$ Second, the "cash or deferred arrangement" (CODA) permits employees to enter into a voluntary salary reduction agreement with employers by which the employer reduces their salaries in return for higher employer pension contributions. ${ }^{20}$ Like voluntary contributions, CODAs receive a more limited subsidy than do non-elective plans. Although taxes on both contributions and interest are deferred, the ceiling on allowable annual contributions for CODAs is $\$ 7,000$, substantially lower than the ceiling for non-elective plans. ${ }^{21}$

Finally, Congress's decision to disfavor individual choice shows in its treatment of Individual Retirement Accounts (IRAs). The lowest ceilings of all apply to contributions to IRAs, a type of plan wholly unrelated to employment. Eligible persons may deduct contributions to IRAs, ${ }^{22}$ but only up to $\$ 2000$ per year. ${ }^{23}$ Additionally, IRAs are generally not available to individuals covered by employer pensions. ${ }^{24}$ Congress is thus most generous to those forms of retirement savings that leave the least room for individual choice.

${ }^{27}$ Contributions to a defined plan generally cannot exceed the lesser of $\$ 30,000$ or $25 \%$ of the participant's compensation. IRC \$§ 415(c)(1)(A), 415(c)(1)(B).

1s A defined benefit plan cannot provide benefits greater than the lesser of $\$ 90,000$ or $100 \%$ of the individual's average salary for his three highest paid years. IRC $\S \S 415$ (b)(1)(A), 415(b)(1)(B). By combining defined contribution and defined benefit plans, an individual can generally accrue more pension wealth than by using either alone, although it is not possible to deduct the full amounts permitted by either type of plan alone. IRC $\S 415(\mathrm{e})$.

19 The appreciation, though, is untaxed. IRC $\S 402(a)(1)$.

${ }^{20}$ Id.

21 IRC § 402(g)(1). The Code defers taxes on both contributions and interest. An employee may make this election at any time permitted by the plan, but may only elect to contribute amounts not yet received as compensation. Treas Reg $\$$ 1.401(k)-(3)(i), $1.401(\mathrm{k})$ (3)(ii). A one-time irrevocable election at the time that eligibility begins is permitted. The tax on both contributions and appreciation is deferred for contributions by self-employed individuals to Keogh plans. IRC §§ 401(c)(1), 401(c)(4).

s2 IRC \& 219(a).

2s IRC \& 219(b)(1)(A). The amount allowable as a deduction is limited to the lesser of $\$ 2,000$ or an amount equal to the compensation an individual may include in gross income for such taxable year. Id.

24 IRC § $219(\mathrm{~g})$. 
Nor does the matter end with the contribution rules. Federal law subjects retirement assets to special restrictions and protections. For example, the Internal Revenue Code subjects withdrawals from subsidized retirement savings plans to income tax, and imposes a penalty of ten percent on most such withdrawals. ${ }^{25}$ Congress also subjects the most highly subsidized retirement savings to even further restrictions. Prior to retirement, individuals can only withdraw pension assets from an employer-sponsored fund in the event of separation from service. ${ }^{26}$ Yet, individuals can withdraw CODA holdings upon separation and also in the event of hardship, ${ }^{27}$ while IRA funds can be withdrawn at any time for any reason. Congress also accords pensions special protections, designed to prevent individuals from reaching old age pensionless. In general, individuals cannot assign or alienate pension wealth, ${ }^{28}$ and pensions enjoy a partial exemption from attachment by creditors. ${ }^{28}$

This system of ceilings and restrictions suggests that the present system of retirement income security has a strong paternalistic coloration. ${ }^{30} \mathrm{I}$ must emphasize the conception of human behavior

${ }^{25}$ IRC \& 72(t)(1).

${ }^{28}$ Rev Rul 56-693, 1956-2 Cum Bull 282, as modified by Rev Rul 60-323, 1960-2 Cum Bull 148; Rev Rul 74-254, 1974-1 Cum Bull 91 (1974). Former Secretary of Labor Elizabeth Dole indicated that she was considering legislation eliminating even this exception by requiring rollover of pension benefits in the event of job separation. Labor Secretary Seeks to Require Workers to Save, NY Times A20 (May 17, 1990).

${ }^{27}$ IRC \& 401(k)(2)(B)(i).

${ }^{28}$ Employee Retirement Income Security Act ("ERISA"), 29 USC § 1056 (d)(1) (1974); IRC § 401(a)(13).

29 Mackey v Lanier Collections Agency \& Service, Inc., 486 US 825, 837 (1988) (dictum); General Motors Corp. $v$ Buha, 623 F2d 455, 463 (6th Cir 1980). Under some circumstances, debtors can exclude pensions from an estate in bankruptcy, particularly if the pension assets are not under the present control of the debtor. In general, therefore, Keogh plans and IRAs are not excluded from the estate. See, for example, Matter of Goff, 706 F2d 574, 588 (5th Cir 1983); Education Assistance Corp. $v$ Zellner, 827 F2d 1222, 1225 (8th Cir 1987). Employer-sponsored pensions are more likely to be held exempt if the debtor has no power to withdraw the funds prior to retirement or disability. Compare Matter of Watkins, 95 Bankr 483 (W D Mich 1988) (employee prohibited from alienating his interest in a pension plan which thus qualifies as a spendthrift trust under state law, and is exempt from the estate), with In re Strehlow, 84 Bankr 241 (Bankr S D Fla 1988) (debtor's ownership of employer corporation and co-trusteeship of plan defeated exemption). But see In re Graham, 726 F2d 1268, 1271-74 (8th Cir 1984) (pension plans never exempt).

${ }^{30}$ Indeed, a non-paternalistic policy would look very different. In a system of elective individual plans, each employee's pension wealth would depend on the employer's view of the net marginal benefit to it of additional employee pension wealth. The employer would determine the marginal benefit by evaluating such factors as the employee's willingness to accept wage offsets for pension benefits; the tax benefit attributable to contributions on behalf of the individual employee; and any other advantages or costs associated with pension provisions. But with a group plan, employers must measure the marginal costs and 
that underlies this sort of paternalism. Congress clearly supposes that people are unable to make wise savings decisions for themselves. Congress thus presumably favors nonelective plans because it believes that incentives will not adequately encourage savings. Congress accordingly directs employers to include individuals in pension plans who would have chosen not to participate were the decision left to them. Similarly, Congress seems determined, through its system of restrictions on, and protections of, retirement assets, to make certain that individuals will not dissipate their savings.

To say that Congress has designed a paternalistic system is not, however, to say that Congress has designed that system well. On the contrary, the system is deeply flawed. Some of those flaws are simply design glitches, ${ }^{31}$ but some flaws are more deep-seated. In particular, it is hard to justify the pattern of coverage that has resulted from the existing system. Our current reliance on incentives to employers to provide pensions creates coverage gaps among groups of workers with short employment histories and among those who work for firms which are poorly situated to provide pensions. Only about half of the work force at any given time is covered by an employer-sponsored pension plan and only about two-thirds will ultimately receive pension benefits. ${ }^{32}$ Even though many of those with low pension wealth will succeed in providing

benefits of increased coverage with respect to the group of covered employees as a whole, not with respect to the individual employee, since coverage to one cannot be increased without increasing coverage to all. Thus, there will be many individuals in the group whose pension accumulation will exceed (or be less than) the level they would have chosen under a CODA or other plan that allowed them to choose the level of subsidized savings on their own. If consumers save rationally this is an unfortunate result. But if they save too little it is highly desirable. High savers can achieve their preferred level of savings with other assets; low savers will be forced, apparently by paternalistic design, to save more than they might like.

s1 For example, the penalty tax of $10 \%$ on withdrawals from subsidized accounts established by IRC $\S 72(t)$ is not well designed. The tax does not always impose a penalty and at times fails to recapture the tax benefits received. Suppose a taxpayer receives one dollar of income. If he simply invests it in a taxable savings vehicle, he has, after $t$ years, the amount

$$
(1+r(1-6))^{t}
$$

where $\phi=$ tax rate and $r=$ interest rate. If he instead places it in a pension fund and withdraws it after $t$ years, incurring the $10 \%$ withdrawal penalty, he has

$$
.9(1-6)(1+r)^{t}
$$

The tax advantages of deferral increase with $t$; the penalty rate does not. In the early years, the penalty more than outweighs the tax preference; in the later years it is lower. For $\phi=.30$ and $r=.10$, the crossover point is reached at about 3.8 years.

33 See, for example, Laurence J. Kotlikoff and Daniel E. Smith, Pensions in the American Economy 29, 69 (Chicago, 1983). Ultimate rates of pension receipt are extrapolated from coverage rates in the preretirement age group. 
for their retirement, they do not receive the benefits of the subsidy. Perhaps more importantly, some uncovered workers do not succeed in compensating for their lack of pension coverage. The public component of retirement income, Social Security, is seldom adequate to provide income maintenance. ${ }^{33}$ To be sure, the goal of income maintenance has for the most part been met. The vast majority of older Americans are not destitute and have resources sufficient to provide a standard of living as high as that enjoyed prior to their retirement. ${ }^{34}$ However, a group too large to be ignored suffers a dramatic drop in living standards after retirement. ${ }^{35}$ Perhaps the most troubling aspect of current coverage gaps is that the individuals most likely to lack coverage are those low income workers who are in turn most likely to fall below the poverty line in retirement. Congress's particular concern with low income workers shows most clearly in the non-discrimination rules. ${ }^{36}$ The law governing non-elective plans does not require employers to cover all workers. Rather, the conditions of the deduction require that the employer plan satisfy non-discrimination rules which restrict the extent to which higher-paid employees can receive higher benefits. ${ }^{37}$ But in spite of these rules, individuals who are inadequately

ss See, for example, Altman, 42 Tax L Rev at 501 (cited in note 3). The percentage of wages eventually replaced by Social Security has vacillated wildly over the years, and even within cohorts, benefit levels can vary enormously because of income, marital status, and the workforce participation of the secondary earner. For example, in 1971, Social Security replaced only $28.2 \%$ of the unadjusted earnings of a married couple whose career average earnings were between $\$ 12,500$ and $\$ 20,000$, while in 1979 they replaced $99.8 \%$ of the career average earnings of a couple whose lifetime earnings were below $\$ 7,500$. Boskin and Shoven, 1987 Issues in Pension Econ at 125 (cited in note 3). For all households that retired in 1969, replacement rates adjusted for various cost-of-living factors have varied from $33.1 \%$ in 1969 to $94 \%$ in 1979. Id at 133. See generally, id at 123-33. The higher figures for the 1979 period are thought generally to represent an unsustainably high level, and indeed to have caused a crisis in the financing of the system. Feldstein, 81 Pub Interest at 104-05 (cited in note 3).

s4 Laurence J. Kotlikoff, Avia Spivak and Lawrence H. Summers, The Adequacy of Savings, 72 Am Econ Rev 1056 (1982); Boskin and Shoven, 1987 Issues in Pension Econ at 113 (cited in note 3).

${ }^{35}$ Boskin and Shoven, Poverty Among the Elderly (cited in note 3).

se IRC $\S 401$ (a)(4), 410(b). Pension benefits proportional to wages, at least up to the ceiling amounts, are permissible. IRC § 401(a)(5)(B).

${ }^{37}$ IRC $\$ 401(a)(4)$. At first glance, these rules might seem to be motivated by distributive rather than paternalistic impulses. This theory is most clearly expressed by one of its critics. Joseph Bankman, Tax Policy and Retirement Income: Are Pension Plan Anti-Discrimination Provisions Desirable?, 55 U Chi L Rev 790, 805-14 (1988). But non-paternalistic distributive impulses can explain only a small part of the present scheme. The Code does not spell out the mechanism by which employer plans are supposed to effect redistribution, but the drafters apparently assumed that the non-discrimination rules would force high income employees to cross-subsidize low income employees.

Even assuming, for the sake of argument, that cross-subsidization occurs, it cannot explain many features of the current scheme. Cross-subsidization might justify the preference 
served by the present system of pension coverage are typically also in lower income groups. ${ }^{38}$

Under the present pension system, then, those most in need are likely to suffer most from inadequate coverage. It is important to ask, therefore, whether there is some better way to achieve our paternalistic pension goals. But we can address this policy question only with some theory of why paternalistic intervention is required in the first place. Although the most obvious analytical tool is economics, it has been surprisingly difficult to modify economic theory to justify paternalistic aims. The next section examines why.

\section{Neoclassical Economics: Policy Without Paternalism}

\section{A. Economic Savings Theory}

Economists who attempt to evaluate American pension policy face a serious methodological difficulty. They must work with a conception of human behavior fundamentally at odds with the paternalistic world view.

It may help to begin by contrasting economics with common sense. Why do some people not save enough for their old age? From a common sense perspective, individuals who fail to save enough fall into several different groups. Some people, whom I will call myopes, simply do not think very much about the future. They spend money as they receive it. When they retire they are forced to lower their consumption level, and they regret not having saved more. Other people, whom I will call impulsives, worry about providing for their old age, and continually resolve to save more, but find that money burns a hole in their pocket. Such people spend their paycheck the moment they receive it. On Monday they regret the impetuousness of Friday, and promise themselves not to repeat it, yet they find next Friday that temptation is again too great. Still another group, whom I will call impatients, always believe

for employer plans over IRAs, but it cannot explain why CODAs are treated less generously than non-elective employer plans. Since employers can match CODA contributions, direct cross-subsidization seems as likely as in a non-elective plan, and indirect cross-subsidization may occur if higher income employees can be made to absorb fixed costs of fund management. Of course, Congress may simply believe that it is getting a free lunch by forcing employers to pay for pensions. I do not believe that there is any need to comment on the plausibility of this view.

38 For evidence of lower pension coverage among lower income workers, see Freeman, Unions, Pensions and Union Pension Funds at 89, 98-99 (cited in note 3). For evidence that pensions and Social Security combined are most likely to be adequate for those with low incomes, see, for example, Boskin and Shoven, Poverty Among the Elderly at 131 (cited in note 3). 
that present consumption needs are especially pressing. Although they see the need to save for future consumption, they believe that it will be easier to save from next year's wages than from this year's. But when next year comes, current consumption seems more pressing than it did in previous years, and the amount that they ultimately save for retirement is far less than what they anticipated while young. The vagaries of cash flow influence the decisions of impatients much less than they do those of impulsives. Impatients have no cycle of Friday binges and Monday morning regret, but rather plan consciously to spend more this year than next. Finally, some people, whom I will call deliberates, plan when young to consume less as they grow old, and follow this consumption plan without any later regret.

The economic theory of savings behavior rejects these distinctions. Economists instead regard all four savings patterns described above as instances of a single type of rational behavior. All four cases are assimilated to that of deliberates, or rational agents who simply prefer present consumption to saving. ${ }^{39}$

Economic theory postulates a consumer who consumes various goods, whose consumption opportunities are limited by his income, and who is able to choose rationally among the consumption goods he can afford to obtain the bundle of goods he most prefers. The consumer chooses bundles of goods so as to maximize his total utility. In general, such a consumer's decisions will conform to the neoclassical principle of marginalism: The consumer will increase his consumption of any given good until the relative marginal cost of the good equals its relative marginal benefit. ${ }^{40}$ Finally, economic theory assumes that the individual's preferences about various consumption goods, sometimes referred to as his utility function, are stable or unchanging between decisions. This general methodology is referred to as consumer theory. ${ }^{41}$

Economists apply consumer theory to savings decisions by treating present consumption and future consumption as two distinct goods. An individual's decision to save is a decision to defer present consumption in favor of future consumption. Thus the in-

\footnotetext{
s9 See, for example, Hal R. Varian, Microeconomic Analysis 111 (W. W. Norton, 2d ed 1984); Mark Blaug, Economic Theory in Retrospect 297 (Cambridge, 4th ed 1985); Jack Hirshleifer, Price Theory and Applications 78-88 (Prentice-Hall, 4th ed 1988); Mark Kelman, Choice and Utility, 1979 Wisc L Rev 769; Jerome Rothenberg, Consumer Sovereignty, in International Encyclopedia of the Social Sciences 326, 327 (MacMillan and Free Press, 1968). See notes 41-50 and accompanying text.

40 See, for example, Blaug, Economic Theory in Retrospect at 297 (cited in note 39).

42 See, for example, Varian, Microeconomic Analysis at 111 (cited in note 39).
} 
dividual's decision to allocate consumption between temporal periods is analytically identical to the decision to allocate income between two goods in one period. ${ }^{2}$

Utility maximization is merely a descriptive theory that predicts how people will behave in the future based on their past behavior. In order to determine which consumption choices would maximize an individual's welfare, economists must make some further assumptions. Welfare economics provides them by postulating that an individual's preferences, as expressed in the consumption choices he makes, are the only measure of his well-being..$^{43}$ Welfare economics places no substantial restrictions on the content of preferences. ${ }^{44}$

Neoclassical theory is compatible with a startling range of individual choices. An individual's behavior may be self-destructive, repellent, or tasteless and still meet the neoclassical definition of rationality. ${ }^{45}$ In particular, from the perspective of neoclassical theory, there is no important difference between the various types of low savers described above. ${ }^{46}$ Rather, under neoclassical economic theory, impulsives, impatients, and myopes are just varieties of deliberates, or rational utility maximizers who happen to prefer consumption today to consumption tomorrow. The subjective feelings of regret or of unmet expectations which serve in part to distinguish myopes, impulsives, or impatients from deliberates are of no significance. ${ }^{47}$

The conclusion that all savings decisions are potentially rational strikes many as implausible. If utility were directly observable, the irrationality of some savings decisions could be shown directly. Specifically, an individual who sometimes failed to choose his most preferred bundle would violate the hypothesis of rational utility maximization. But economists argue-along with many crit-

\footnotetext{
42 These assumptions-and consumers who conform to them-are sometimes referred to as neoclassical to distinguish them from other possible assumptions about behavior that might be called economic. Id.

is This is implicit in the use of individual preferences in welfare analysis: The optimum of the consumer is determined solely by reference to his preferences. See, for example, Hirshleifer, Price Theory and Applications at 78-88 (cited in note 39). See also Kelman, 1979 Wisc L Rev at 769 (cited in note 39) (criticizing extreme commitment to consumer sovereignty); Rothenberg, Consumer Sovereignty at 327 (cited in note 39).

"Neoclassical theory does place some formal restrictions on the content of individual preferences, and it assumes that preferences are complete, continuous, reflexive and transitive. See, for example, Varian, Microeconomic Analysis at 111-12 (cited in note 39).

45 Hirshleifer, Price Theory and Applications at 9 (cited in note 39).

46 See note 39 and accompanying text.

17 Kelman, 1979 Wisc L Rev at 778-87 (cited in note 39) (discussing and attacking neoclassical disregard of subjective phenomena).
} 
ics of classical utilitarianism-that only choices, and not their corresponding utility, can be observed. Since the preferences of a rational individual cannot be observed, economists assert, we cannot directly test the hypothesis that individuals maximize utility. Rather, the utility of a neoclassical individual must be inferred from revealed preferences, that is, from the consumption choices that that individual actually makes. ${ }^{48}$ Economists regard only one form of evidence as undermining their basic hypothesis, and that is evidence of inconsistency. ${ }^{49}$ In general, a set of individual choices results from preference maximization if and only if, when choosing between bundle $\mathrm{A}$ and bundle $\mathrm{B}$ on different occasions, the consumer consistently chooses the same one. If the consumer sometimes chooses bundle $\mathrm{A}$ and sometimes bundle $\mathrm{B}$, his choices are inconsistent. ${ }^{50}$

Choice-based welfare theory has some strong analytical implications: Welfare theory does not recognize that an individual can make mistakes about his own preferences; nor can an individual fail rationally to implement those preferences; nor can outsiders even ascertain an individual's optimal consumption bundle except by examining his choices. This vision of human behavior means that paternalistic savings policy cannot improve individual welfare. As the very phrase "consumer sovereignty" suggests, economists applying consumer theory assume that consumers know their own interests best. Restrictions on individual choice of the kind that permeate our existing pension system ${ }^{51}$ are difficult for neoclassical economists to accept. ${ }^{\mathbf{3 2}}$ But neoclassical economists do not believe that national savings rates will, in the absence of government policy, always attain ideal levels. The next section will explain the neoclassical approach to savings policy, an approach which has colored many recent reform proposals.

\footnotetext{
48 See, for example, Hal R. Varian, Intermediate Microeconomics 114 (W. W. Norton, 1987); see generally, id at 114-30.

40 See, for example, id at 114-30.

${ }^{30}$ Id at 121-24. It must be emphasized that $A$ and $B$ are bundles of items, not individual items. Suppose that blueberries cost $49 \mathrm{c}$ a pint while raspberries cost $\$ 3.29$ a pint. An individual who buys one pint of blueberries on Tuesday and one pint of raspberries on Thursday does not necessarily exhibit inconsistency. Suppose, though, that over the course of a year the individual buys 17 pints of raspberries and 42 pints of blueberries. This combination can be thought of as a bundle. Over the course of the next year, the individual buys a bundle consisting of 12 pints of blueberries and 61 pints of raspberries. If the individual's income and the relative prices of all goods have remained the same, the choice of these rather different bundles would constitute an inconsistency, Id.

s1 See notes 9-29 and accompanying text.

82 Peter J. Ferrara, Social Security: Averting the Crisis 81 (Cato Institute, 1982).
} 


\section{B. Efficiency-Based Reform Proposals}

How would neoclassical economists remake the pension system? Inevitably, they see no role for paternalism in pension policy. Rather, they stress a wholly different aspect of pensions and Social Security: how these programs affect national savings and consequently national economic growth. They regard the question of pension policy as only part of a larger concern for the promotion of economic efficiency. ${ }^{53}$

As we have seen, neoclassical economists must, as a general proposition, insist on freedom of individual choice. As a result, they express little interest in employer pension plans, believing that if individual choice is rational, the employer has no role to play as an intermediary. They also tend to be hostile to any system of savings subsidies, since a system of savings subsidies financed by taxes merely distorts individual choice and reduces overall welfare. ${ }^{54}$ Subsidies with ceilings are less distorting, but only to the extent that they have no effect on national savings levels. ${ }^{55}$

ss "[T]he goal of public policy toward pensions is to eliminate artificial obstacles to voluntary private market solutions for generating retirement income." Ippolito, Pensions, Economics and Public Policy at 207 (cited in note 4).

st Many economists do support the tax deductibility of pension contributions, but not for paternalistic reasons. Instead, they believe that consumption is preferable to income as a tax base for efficiency or equity reasons. They defend the pension deduction because they regard it as the removal of a bad tax rather than as a subsidy, which they would oppose. See, for example, Ippolito, Pensions and Economics at 35-37 (cited in note 4).

${ }^{B S}$ If, as the economic model implies, individuals make decisions only on the margin, a subsidy with a ceiling will cause any consumer whose preferred savings level exceeds the

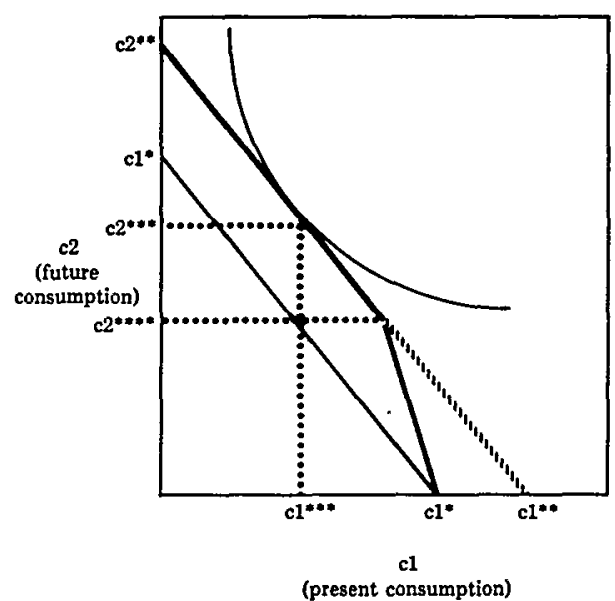

ceiling amount to shift funds into the tax-favored vehicle without changing his total level of savings. In the diagram above, the thin line indicates the individual's initial budget constraint, while the bent heavy line indicates a tax subsidy with a ceiling at $c 2^{* * * *}$. If the 
In the neoclassical world, a mandatory savings plan has no more paternalistic justification than a tax subsidy. If the level of savings required by the plan is above the level the individual would have chosen if left to his own devices, so that individuals are initially at the optimum, mandatory savings schemes will reduce welfare by raising savings above the optimal point. Conversely, if the level of savings required by the plan is below the level that would be chosen freely, the mandatory plan will have no effect; it will do no harm but serve no purpose. ${ }^{.6}$

Nevertheless, efficiency-oriented economists are not hostile to all pension reform proposals. ${ }^{57}$ Although neoclassical economics implies that savings levels are individually rational, it also suggests that they may be below the socially optimal level. This is a result of a simple externality, referred to as the overlapping generations

consumer's optimal savings is, as in the diagram, a savings level like $c 1^{* * *}, \mathrm{c2} 2^{* * *}$ that is above the ceiling level, the tax subsidy operates just like a flat rate income transfer. Such a transfer produces a parallel shift, in this case one which produces the straight line extending from $\mathrm{c2**}$ to $\mathrm{c1}^{*}$.

Of course, these subsidies with ceilings do have a peculiar distributive effect, namely, they provide a transfer in the amount of the subsidy. See William G. Gale and John K. Scholz, IRAs and Household Saving 2 (Jul 16, 1990) (on file with U Chi L Rev). Compare Maurice MacDonald, Food, Stamps, and Income Maintenance 52-58 (Academic, 1977) (food stamps).

so The reason that mandatory plans may have no effect is similar to the reason that subsidies with ceilings may be like income transfers. See note 57 . The consumer's original budget constraint is the straight line connecting $c 1^{*}$ and $c 2^{*}$. A mandatory plan requiring savings at level $c 2^{* * *}$ will have no effect on a consumer who planned to consume $c 2^{* *}$, greater than $c 2^{* * *}$.

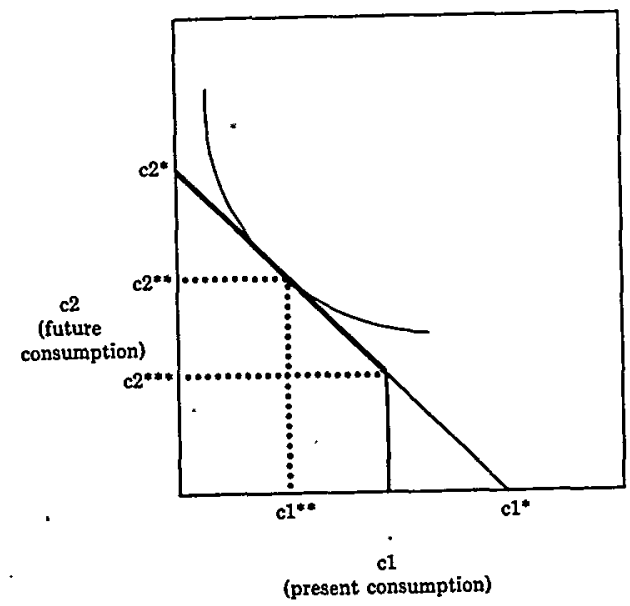

57 See, for example, Boskin, Too Many Promises at 139-71 (cited in note 3); Boaz, NY Times at A27 (cited in note 4); Scoville, NY Times at A23 (cited in note 4). See notes 58-64 and accompanying text. 
problem: savings affects the welfare of future generations, but those generations play no role in determining today's savings. Thus, the national savings level may be too low to protect the interest of future generations.

Economists who accept this argument offer a number of policy prescriptions. They argue that policies such as capital taxes exacerbate the problem of low savings and are therefore undesirable. ${ }^{58}$ They endorse various pension tax subsidies as a subsidiary component of their general advocacy of capital tax cuts, ${ }^{59}$ such as the Bush Administration's proposed capital gains cut. The Bush Administration has also proposed a more restricted variant, a Family Savings Account that would, with certain income restrictions, permit tax free accumulation on up to $\$ 2500$ in annual contributions. ${ }^{60}$ These accounts would be less paternalistic than IRAs, because in seven years the funds could be withdrawn for any purpose without incurring tax on the appreciation. ${ }^{61}$ Other efficiency proposals include attempts to broaden the scope of existing retirement tax breaks. Both the Bush Administration and Senator Lloyd Bentsen have introduced measures, for example, that would raise IRA contribution ceilings and permit tax free transfers from them to certain other investments. ${ }^{62}$

so See, for example, Lawrence H. Summers, Issues in National Savings Policy, in F. Gerard Adams and Susan M. Wachter, Savings and Capital Formation 65, $73-75$ (D. C. Heath, 1986). The overlapping generations argument is not wholly dispositive of the question of capital taxes since the true cost of such taxes depends in part on the alternatives to theory. Labor taxes have adverse efficiency consequences also, though possibly fewer than capital taxes, especially since labor supply does not involve externalities like the overlapping generations problem. Thus, while efficiency criteria do not clearly dictate whether we should tax interest, economists who are concerned about efficiency tend to favor exempting interest income.

so See, for example, Ippolito, Pensions, Economics and Public Policy at 207-18 (cited in note 4).

${ }^{60}$ HR Rep No 3972, § 202, 101st Cong 2d Sess (Feb 7, 1990) (Archer).

or Id at $\$ 202$ (e).

62 Id at $\S 201$ (housing; administration proposal); S 612, § 101, 102d Cong, 1st Sess (Aug 2,1991 ), in 137 Cong Rec S12183 (daily ed, Aug 2, 1991) (housing and education; Bentsen proposal). The Bush proposal was also limited to families with income of less than $\$ 120,000$ per year. HR $3972, \S 292(\mathrm{c})(3)$. Modified IRA proposals that would permit similar withdrawals include HR 960, §301, 102d Cong, 1st Sess (Feb 19, 1991), in 137 Cong Rec H1023 (daily ed, Feb 19, 1991) (Delay, R-Tex); HR 1074, 102d Cong, 1st Sess (Feb 21, 1991), in 137 Cong Rec H1136 (daily ed, Feb 21, 1991) (Neal, D-Mass); HR 1291, 102d Cong, 1st Sess (Mar 6, 1991), in 137 Cong Rec H1454 (daily ed, March 6, 1991) (Wylie, R-Ohio); HR 1406, 102d Cong, 1st Sess (Mar 12, 1991), in 137 Cong Rec H1669 (daily ed, Mar 12, 1991) (Pickle, D-Tex); HR 1731, 102d Cong, 1st Sess (Apr 11, 1991), in 137 Cong Rec H2177 (daily ed, Apr 11, 1991) (Hubbard, D-Ky); HR 2340, 102d Cong, 1st Sess (May 14, 1991), in 137 Cong Rec H3036 (daily ed, May 14, 1991) (Tallon, D-SC); HR 2478, 102d Cong, 1st Sess (May 29, 1991), in 137 Cong Rec H3709 (daily ed, May 29, 1991) (Gillmor, R-Ohio); S381, § 301, 102d 
What about mandatory plans? Here again sophisticated neoclassical economists are willing to support some degree of intervention. The same overlapping generations concern that leads some economists to accept the principle of subsidies also leads them to accept the principle of forced savings. Other concerns are at work as well. Neoclassical economists recognize that individuals may deliberately not save in order to take advantage of welfare-type Social Security. ${ }^{63}$ With such concerns in mind, efficiency-oriented commentators insist on the importance of a funded Social Security program, or a mandatory universal pension system ("MUPS"). ${ }^{64}$

Neoclassical economists also have their own way of looking at restrictions on and protections of pension assets. They believe that restrictions on pension withdrawals serve no good purpose and that the welfare of a consumer can never be improved by reducing the choices available to him. A deliberate consumer who withdraws from his pension fund in the absence of restrictions does so for a good reason. Similarly, the special protection from creditors accorded to pensions cannot be justified. The argument for debtor protection appears to be that creditors are more likely to be riskneutral firms and therefore better risk-bearers than personal debtors, who are likely to be risk-averse. ${ }^{65}$ Thus, economic efficiency might seem to dictate that the risk of personal bankruptcy be shifted to those firms. Yet some neoclassical economists argue that such differences in attitudes toward risk do not justify the present scheme of compulsory protection, since creditors and debtors could achieve an efficient allocation of risk by contract. ${ }^{68}$ Economic theory, moreover, suggests strong reasons against providing special

Cong, 1st Sess (Feb 6, 1991), in 137 Cong Rec S1723 (daily ed, Feb 6, 1991) (Wallop, R-Wy) (same as HR 960).

${ }^{63}$ Boskin, Too Many Promises at 10 (cited in note 3).

64 Because Social Security taxes are used to pay current benefits and are not invested, Social Security does not contribute to national savings. Commentators have made this point in the context of the dispute about the extent to which Social Security reduces private savings. See note 63. However, even if Social Security did not reduce private savings at all, an unfunded Social Security system would obviously produce a lower national savings rate than a funded system. Because economists believe that individuals choose rationally, they favor reforming the Social Security system so that it is not only funded, but privatized. S 2026 (cited in note 4); HR 3083 (cited in note 4); Boaz, NY Times at A27 (cited in note 4). The Porter and Symms proposals would permit transfer of Social Security funds to IRAs or other qualified plans and would thus allow some degree of private control of investment management. They thus contrast with proposals which would create a public trust fund. See, for example, Scoville, NY Times at A23 (cited in note 4).

${ }^{65}$ See generally Varian, Intermediate Microeconomics at 211-25 (cited in note 48).

${ }^{8 B}$ Compare Richard A. Posner, The Rights of Creditors of Affiliated Corporations, 43 U Chi L Rev 499, 507-09 (1976). 
protection to pensions. One argument is that debtors are better situated than creditors to evaluate their own risk of bankruptcy or default and to decide whether to incur additional debt. Sheltering pension assets from creditors blunts the debtor's incentive to act on this information, creating a moral hazard problem. ${ }^{67}$ In addition, when default or bankruptcy becomes inevitable, debtors may transfer to pensions to shelter them from creditors. Special protections for pensions thus arguably provide debtors with a means of defrauding creditors.

Neoclassical economics thus provides grounds for rejecting some of the restrictions in the present system, but neoclassicists are still willing to accept a fair range of restrictions on individual choice. Notably, though, the restrictions economists accept are restrictions directed at externalities, not those driven by paternalism. Paternalism thus remains outside the range of the concerns of neoclassical economists.

\section{The Non-Neoclassical Critics: Pragmatic Paternalism}

The present system of retirement income security has been criticized not only by neoclassicists but also by those who, like Congress, believe that individuals may fail to save as much as they should for their retirement. These critics, who advocate paternalistic intervention, operate from a more pragmatic, less theoretical perspective than the neoclassical commentators.

Although these commentators see a need for paternalistic intervention, they do not always express their paternalism directly. ${ }^{68}$ Rather, they emphasize the distributive shortcomings of the present pension system. ${ }^{69}$ Some of the complaints couched in distribu953 (1981)

sa A typical statement is made by Nancy J. Altman:

[I]t is extremely difficult to forecast how much one will need at retirement and, therefore, how much one must save during one's working life. Even if an individual could make the necessary calculations ... the savings would provide a frequently irresistible temptation to meet more immediate needs such as those arising from illnesses, unemployment, home purchases, and children's education.

Altman, 42 Tax L Rev at 502 (cited in note 3) (footnote omitted). More explicit discussions include Bankman, 55 U Chi L Rev at 790-835 (cited in note 37): Bruce Wolk, Discrimination Rules for Qualified Retirement Plans: Good Intentions Confront Economic Reality, 70 Va L Rev 419, 466 (1984); James Tobin, The Future of Social Security: One Economist's Assessment, in Theodore R. Marmor and Jerry L. Mashaw, eds, Social Security: Beyond the Rhetoric of Crisis 41 (Princeton, 1988).

"9 Altman, 42 Tax L Rev at 470 (cited in note 3); Graetz, $135 \mathrm{U} \mathrm{Pa} \mathrm{L} \mathrm{Rev} \mathrm{at} 865$ (cited in note 4). 
tional terms are truly about fairness. Certainly these complaints are legitimate, but no methodological innovations are needed to make them. The neoclassical approach can accommodate distributive as well as efficiency concerns. ${ }^{70}$ Neoclassicists who emphasize distribution favor taxing interest income, which is disproportionately received by the more affluent. ${ }^{71}$ Observers concerned with distribution regard deductions to retirement income savings as deviations from an ideal tax base that must be justified on other grounds. ${ }^{72}$ From this neoclassical distributive perspective, the current pension system is seriously flawed. The use of deductions as the primary tax subsidy tool favors the well-to-do. While the present system of tax subsidies, with its ceilings and non-discrimination rules, to some extent modulates these inequities, it creates others by relying on employers. Left to their own devices, employers will provide more generous pensions to high income workers. Only about half of the work force is covered by an employer-sponsored pension plan, and only about two-thirds will ultimately receive pension benefits. ${ }^{73}$

Yet if ostensibly distributive concerns had no paternalistic component, there would be no need to resort to pension policy at all. Rather, progressive tax cuts and transfers could redistribute income to people during their working life, since individuals can in principle save by themselves. ${ }^{74}$ In fact, though, some distributive commentators implicitly reject the neoclassical view that all savings levels are rational. Rather, they believe that savings levels should be roughly proportional to income. To put it differently, they feel that the proportion of wage income that should be replaced by retirement income, or the replacement ratio, should be roughly constant across income groups, and should enable people to maintain their pre-retirement standard of living. ${ }^{76}$ Most Ameri-

70 An emphasis on distribution, though, will change certain policy prescriptions. See Deborah Weiss, Welfare for the Rich: The Case for Progressive Tax Credits for Savings § III (unpublished manuscript on file with U Chi L Rev).

"1 See, for example, Richard Goode, The Superiority of the Income Tax, in J. Pechman, ed, What Should Be Taxed, Income or Expenditure? 49, 56, 72-73 (Brookings Institution, 1980).

72 As the efficiency-oriented commentators suggest, these revenue losses are to some extent offset by countervailing efficiency gains because the distortionary tax on capital income is removed. These gains may in turn be reduced to the extent other taxes are levied to make up the revenue shortfall.

${ }_{73}$ Laurence J. Kotlikoff and Daniel E. Smith, Pensions in the American Economy 26, 69 (Chicago, 1983).

${ }^{74}$ Weiss, Welfare for the Rich \$ III (cited in note 70).

${ }^{75}$ Graetz, $135 \mathrm{U} \mathrm{Pa} \mathrm{L} \mathrm{Rev} \mathrm{at} \mathrm{855-56} \mathrm{(cited} \mathrm{in} \mathrm{note} \mathrm{4).}$ 
cans meet even this stricter definition of rationality. ${ }^{76}$ Most retired Americans are able to maintain a standard of living at least as high as that enjoyed during their working years, and only a relatively small group falls below the poverty line. ${ }^{77}$ A significant group of retired Americans, though, does suffer a dramatic drop in living standards after retirement. ${ }^{78}$ Not surprisingly, individuals who had low incomes during their working lives are far more likely to fall below the poverty line in retirement. ${ }^{79}$ Interestingly, individuals whose relative standard of living drops are more often in higher income groups. ${ }^{80}$ The larger drop among higher income workers appears to be primarily due to the effects of a progressive system of Social Security benefits. ${ }^{81}$ In the absence of public assistance, those with less income during their working lives would suffer relatively greater declines in replacement rates. ${ }^{82}$

Distributive-paternalistic observers thus wish to broaden the coverage of retirement income security programs without increasing the subsidy to the already covered and presumably affluent. The suggested alternatives are themselves problematic, however. An across-the-board reduction of capital taxes would be an inefficient means to this end, since most of the subsidy would be paid to well-to-do consumers who are already high savers. ${ }^{83}$ Some distributive-paternalistic observers would consider allowing subsidies (up

\footnotetext{
76 Although the public component of retirement income-Social Security and subsidized pensions-is seldom adequate to provide income maintenance, most comprehensive studies suggest that the goal of income maintenance has been for the most part met. See note 68 .

${ }^{77}$ Kotlikoff, Spivak, and Summers, 72 Am Econ Rev at 1060-66 (cited in note 34); Boskin and Shoven, 1987 Issues in Pension Econ at 113 (cited in note 3).

78 Boskin and Shoven, Poverty Among the Elderly (cited in note 3).

79 Id at 128-31.

so Id at 131-32.

Q1 Id at 132.

82 The lower propensity of those with lower incomes to save suggests that they would suffer disproportionately from the elimination of Social Security. See Emily C. Lawrence, Poverty and the Rate of Time Preference: Evidence from Panel Data, $99 \mathrm{~J}$ Pol Econ 54, 6669 (1991); M. Kurz, R. G. Spiegelman, and R. W. West, The Experimental Horizon and the Rate of Time Preference for the Seattle and Denver Income Maintenance Experiments: $A$ Preliminary Study, Stanford Research Institute, Research Memorandum 21 (Nov 1973); Steven F. Venti and David A. Wise, The Determinants of IRA Contributions and the Effect of Limit Changes, in Zvi Bodie, John B. Shoven, and David A. Wise, eds, Pensions in the U.S. Economy 9, 11-14 (Chicago, 1988).

ss A number of studies suggest that the well-to-do have lower rates of time preference, and thus a greater tendency to save for the future. Lawrence, $99 \mathrm{~J}$ Pol Econ at 66-69 (cited in note 82); Kurz, Spiegelman, and West, The Experimental Horizon at 24 (cited in note 82). Similarly, many studies have found that higher income taxpayers are more likely to contribute to IRAs. See, for example, Venti and Wise, The Determinants of IRA Contributions and the Effect of Limit Changes at 11 (cited in note 82).
} 
to a low ceiling amount) for voluntary plans like IRAs, CODAs, or the Bush-Bentsen proposals. ${ }^{84}$ Although these devices would not have all the distributive problems of a capital gains cut, they would suffer from another defect: those most in need of paternalistic help are the least likely to be induced to save by incentives.

Consequently, distributive-paternalistic commentators are likely to endorse schemes with a mandatory component. ${ }^{85}$ Some merely advocate a strengthening of the current system of employer pensions, in which incentives at the employer level are combined with mandatory participation by covered individuals. Improved coverage would be achieved by strengthening the non-discrimination rules. ${ }^{88}$ However, even if the existing system of employer pensions were extended, the voluntary nature of firm pension coverage would produce far from universal coverage. Individuals who work for firms, generally small ones without pension plans, cannot be covered and thus cannot receive the tax subsidy. ${ }^{87}$ Most distributive-paternalistic observers thus endorse a completely mandatory scheme, such as a mandatory employer pension, or a MUPS unrelated to employment. ${ }^{88}$ These proposals, too, have problems. Mandatory employer-sponsored plans might remedy the current gaps in coverage, but small firms are likely to be inefficient providers of what is a sophisticated financial service. A MUPS would be effective, but seems politically unlikely. ${ }^{89}$

In short, a distributive-paternalistic observer would like an incentive-based scheme that is effective in encouraging those least likely to save to do so without help. But although these critics have assumed the need for paternalism, they have made no attempt to provide a rigorous model for analyzing why paternalism is necessary or how paternalistic goals should be achieved. The distributive critics, whatever the merits of their proposals, have done no better than the neoclassicals in explaining why paternalism is necessary in the first instance.

s4 Graetz, $135 \mathrm{U} \mathrm{Pa}$ L Rev at 890-900 (cited in note 4).

ss President's Commission on Pension Policy, Coming of Age: Toward a National Retirement Income Policy 41-44 (1981); Bankman, $55 \mathrm{U}$ Chi L Rev at 825-26 (cited in note 37); Wolk, $70 \mathrm{Va}$ L Rev at 466-67 (cited in note 68).

${ }^{88}$ Altman, $42 \mathrm{Tax} \mathrm{L}$ Rev at 456-500 (cited in note 3).

87 Andrews, The Changing Profile of Pensions in America at 164-69 (cited in note 4). The connection between firm size and worker coverage has been established in many studies. See, for example, Ippolito, Pensions, Economics and Public Policy at 189-90 (cited in note 4).

88 President's Commission on Pension Policy, Coming of Age at 41-44 (cited in note 85); Bankman, 55 U Chi L Rev at 825-26 (cited in note 37); Wolk, 70 Va L Rev at 466-67 (cited in note 68).

82 Graetz, $135 \mathrm{U} \mathrm{Pa} \mathrm{L} \mathrm{Rev} \mathrm{at} \mathrm{907-08} \mathrm{(cited} \mathrm{in} \mathrm{note} \mathrm{4).}$ 
It is difficult to design such a paternalistic scheme in the absence of an explanation for why individual choice fails. We still lack the model of human behavior we need. The following sections attempt to fill this gap.

\section{Modified Neoclassical Paternalism: Myopia}

The neoclassical model regards all low savers as "deliberates"-rational utility maximizers who prefer present consumption to future consumption. As a consequence, the neoclassical model supposes that interventionist savings policy cannot improve individual welfare. But the view that individual savings decisions are necessarily optimal strikes many commentators as dubious. ${ }^{90}$ Even those who in general accept the neoclassical argument for consumer sovereignty have misgivings about applying neoclassical welfare analysis to savings. In particular, many economists and philosophers question whether it is rational to value future well-being less than present well-being. ${ }^{91}$

Those who take this approach exclude from the class of deliberates individuals who are "myopes," or who overly discount the future. Philosophers generally analyze myopia in terms of discounting future consumption, while economists analyze this problem in terms of discounting future utility. ${ }^{.2}$ Either approach is a

'0 See, for example, A. C. Pigou, The Economics of Welfare 24-30 (MacMillan, 4th ed 1960); Eugen V. Bohm-Bawerk, The Positive Theory of Capital 253-59 (William Smart, trans) (MacMillan, 1891); Martin Feldstein, The Optimal Level of Social Security Benefits, 100 Q J Econ 303, 307-08 (1985); R. F. Harrod, Towards a Dynamic Economics 40 (MacMilIan, 1948); F. P. Ramsey, A Mathematical Theory of Savings, 38 Econ J 543 (1928). Philosophers endorsing this view include John Rawls, A Theory of Justice 293-98 (Belknap, 1971); Jon Elster, Ulysses and the Sirens 66-68 (Cambridge, rev ed 1984). See note 92 and accompanying text.

" See note 92 and accompanying text.

92 An individual's intertemporal utility function is a function of the amount consumed in all future periods $s$ (written $c_{s}$ ), and of the future periods $s$ in which consumption occurs. It is generally assumed that the utility of future consumption has a particular form, such that the utility that consumers receive at time $t$ from consumption $c_{s}$ at time $s$ is equal to some function $u\left(c_{s}\right)$ reduced by a discount factor $\phi(s)$. The function $u\left(c_{s}\right)$ is the same for all periods $s$ but the discount function $\phi(s)$ depends on $s$, that is, on the time of consumption. Thus, the consumer's utility for $c_{s}$ is $\phi(s)$ times $u\left(c_{s}\right)$, or $\phi(s) u\left(c_{s}\right)$. His total utility from consumption in all periods can be written as the sum of his utility from consumption in each future period.

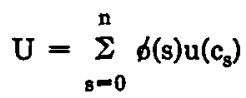

The most commonly used discount function is of the so-called exponential form $R^{2}$ where $R^{\prime}$ is any constant, usually less than 1 . The term $R$ in this expression is often written 
theory of myopia. In common sense terms, myopia is an irrational preference for present consumption over future consumption. In economic terms, myopia is a discount rate that is irrationally larger than zero, or irrationally higher than the interest rate. ${ }^{83}$ Thus even consistent preferences may be irrational.

The irrationality of some consistent preferences is, of course, deeply at odds with neoclassical theory. Pure neoclassical theory places few restrictions on preferences, and consequently on which savings patterns are rational. Neoclassical theory regards even very low savings levels as rational. But the discount rate, in combination with the interest rate, determines the level of individual savings over time, and if certain preferences are myopic, then the associated savings patterns are irrational. Again, this can be put in simple economic language. With a positive interest rate, the view that the rate at which an individual should discount the future should be zero implies that consumption should rise over the individual's lifetime. The claim that the discount rate should equal the interest rate implies that a rational agent would spread consumption more or less evenly over a lifetime..$^{94}$

The theory of myopic behavior provides a justification for intervention in individual savings decisions as well as guidance about the optimal savings point and the appropriate corrective tools. My-

in the form $1+p^{s}$ so as to make explicit the rate of time preference, $p$. The rate of time preference, $p$, is in some respects similar to the interest rate. In particular, the rate of time preference will equal the interest rate in equilibrium as long as there are no taxes or other complications.

The best known statement by an economist of the view that positive time preference is irrational is Pigou's hypothesis of a faulty telescopic faculty. Pigou, The Economics of Welfare at 24-30 (cited in note 90). See also Bohm-Bawerk, The Positive Theory of Capital at 253-59 (cited in note 90); Feldstein, $100 \mathrm{Q} \mathrm{J}$ Econ at 307-08 (cited in note 90); Harrod, Towards a Dynamic Economics at 40 (cited in note 90). Philosophers endorsing this view include John Rawls, $A$ Theory of Justice at 293-98 (cited in note 90); Jon Elster, Ulysses and the Sirens at 67 (cited in note 90).

${ }^{\circ 3}$ See note 94 and accompanying text.

o4 $\operatorname{Max} u\left(c_{1}\right)+(1+p)^{-1} u\left(c_{2}\right)$ s.t. $Y=c_{1}+(1+r)^{-1} c_{2}$

The first order conditions of this problem imply

where $u\left(c_{1}\right)=$ utility of period 1 consumption;

$$
\frac{u_{c 1}}{u_{c 2}}=\frac{(1+r)}{(1+p)}
$$

$\mathrm{u}\left(\mathrm{c}_{2}\right)=$ utility of period 2 consumption;

$\mathbf{r}=$ interest rate; and

$\mathrm{p}=$ rate of time preference.

Thus, when $r=p$, the marginal utility of consumption in the two periods is equal, so under the usual assumption, consumption must be constant. Notice that if $p=0$ and $r>0$, the individual's consumption must rise over time. The distinction between uniform consumption over time and a zero rate of time preference is obviously fairly technical, and it is not always easy to discern which of the two positions non-economists are advocating. 
opes in many respects resemble their deliberate cousins: they make decisions on the margin, and their behavior can be manipulated with neoclassical tools. For a myope, the optimal level of savings is simply the level that an individual with the rational discount rate would choose. Both tax subsidies and mandatory plans can be used to achieve this. A tax subsidy in the amount of the difference between the myope's discount rate and the rational discount rate will cause the myope to save at the rational level. The use of tax ceilings will undercut the effectiveness of any subsidy, since myopes are still marginalist creatures.

A properly designed mandatory plan would similarly move myopes to the optimal savings level. The appropriate level of mandatory savings requires some further refinement of the theory, in an assumption as to whether the individual's myopia extends to future income as well as to future utility. If the individual's myopia extends to future income-that is, if the myope does not think about the fact that he will receive Social Security benefits in the future-he will not reduce his voluntary savings. Thus, a mandatory plan need only require the individual to save the difference between what he would have saved and the optimal level. ${ }^{95}$ Myopic preferences also justify withdrawal restrictions on pension wealth and the protection of pension benefits from creditors. Without such limitations, myopes might undo the effects of paternalistic policy.

A satisfactory theory of myopia would thus justify and provide guidance for interventionist pension policy. But although the theory of myopia allows us to employ some economic methodology, it remains so deeply inconsistent with neoclassical assumptions that the myopia theorist must jettison some valuable neoclassical structures. Presumptions that high discount rates or steeply declining consumption are irrational disregards individual preferences, and cannot easily be squared with neoclassical methodology. That is a loss. The neoclassical equation of consistency and rationality may be trivial, but it provides clear rules for determining which decisions are rational and which are not. But if, as the myopia hypothesis requires, some consistent decisions are to be classified as irrational, some substitute criteria for rationality is needed. Without a

os If the receipt of future benefits will offset, to some degree, the individual's present savings, the mandatory plan must force the individual to save more than this difference, perhaps the entire optimal amount. Still, although not logically implied by myopic preferences, myopia toward future benefits does seem to be a plausible corollary of such preferences. 
differentiating criteria, it is hard to explain why a consumer's discount rate can be ignored while the other parameters of his utility function must be respected. ${ }^{96}$ And even if discount rates differ from other parameters, why select low discount rates as rational? Why should consumption be smooth or gradually increasing? Why not fluctuating, or decreasing, or rapidly increasing?

In, the hope of improving on the theory of myopia, the next few sections move from philosophy to experimental psychology, examining empirical evidence that intertemporal choices do not result from the rational maximization of stable preferences. This evidence, I will argue, provides a less arbitrary reason than the theory of myopia for rejecting consumer sovereignty arguments, although it cannot provide a complete foundation for a welfare standard.

\section{The Psychology of Impatience and Impulsiveness}

The theory of myopia has not convinced neoclassical economists to relinquish their model of human behavior, for it provides no precise theoretical reason for distinguishing myopes from deliberates. In this section, I will suggest that impatients and impul-. sives cannot be forced into the neoclassical model. A look at psychology reveals that their behavior exhibits inconsistency, the one fact that neoclassical economics cannot explain.

\section{A. Time-Inconsistent Preferences}

Suppose that on December 25, 1990, an individual is given a choice between $\$ 100$ on December 25,1994 , and $\$ 110$ on January 1 , 1995 ; he chooses the $\$ 110$. However, if he were given the same choice on. December 24,1994, he would prefer the $\$ 100$ the next day rather than wait eight days for $\$ 110$. When, as in this example, the individual would make a different decision at a later period, the decision is said to be time-inconsistent or dynamically inconsistent. $^{.77}$ Intertemporal inconsistencies are a special case of the

\footnotetext{
9e These considerations have caused many to defend consumer sovereignty in the intertemporal context. Otto Eckstein, Investment Criteria for Economic Development and the Theory of Intertemporal Welfare Economics, 71 Q J Econ 56, 74-79 (1957); P. T. Bauer, Economic Analysis and Policy in Underdeveloped Countries 112-15 (Duke, 1957).

92 The phenomenon of time inconsistency was first analyzed in R. H. Strotz, Myopia and Inconsistency in Dynamic Utility Maximization, 23 Rev Econ Stud 165 (1957). However, as Derek Parfit points out, Hume had described it quite precisely:

[I]n refiecting upon any action which I am called upon to perform a twelvemonth hence, I always resolve to prefer the greater good, whether at that time it will be contiguous or remote. ... But on a nearer approach ... a new inclination to the good springs up, and makes it difficult for me to adhere rigidly to my first purpose and
} 
more general phenomenon of inconsistent choice, which can also occur within a single period.

A growing body of laboratory evidence suggests that many human subjects make dynamically inconsistent choices. The most commonly accepted explanation for this phenomenon is that individual preferences are not stable.98

1. How time-dependent change causes dynamically inconsistent choices.

Many different factors can cause preferences to change. One of the most important is the passage of time. If, over time, the consumer's preferences change, the individual's utility for consumption at time $t$ will vary with the time at which preferences are evaluated. This stream of changing preferences can be represented by a series of utility functions for each period.99

If the consumer's preferences have changed, then behavior which the individual regards as optimal in one period will not appear to be optimal in the next. If an individual's preferences change so that consumption now relative to consumption in other periods seems more pressing than it did yesterday, then the individual corresponds to the impatient consumer described earlier. ${ }^{100}$ In general, preference change will produce inconsistency. ${ }^{101}$ It

resolution.

David Hume, 2 A Treatise of Human Nature, Bk III, Pt II, Sec VII, quoted in Derek Parfit, Reasons and Persons 159 (Oxford, 1984).

${ }^{88}$ See sources cited in note 8. See also notes $103-05$ and 117-20 and accompanying text.

"O Alternatively and more succinctly, it can be represented by a single meta-utility function that varies with time $t$. A changing intertemporal utility function specifies the utility of the individual at some time $t$ as a function of $t$,

$$
U_{t}=U\left(c_{0} \ldots c_{s} \ldots c_{n}, 0 . s \ldots n, t\right) s=0 \ldots n
$$

This function evaluated at any given $t$ is the utility function for that period. If, as in the one period or static case, the individual's preferences are perfectly stable, then preferences at any time $t$ can be represented by a utility function that does not vary with $t$, the time at which preferences are evaluated. In contrast, for an individual who lives for $n$ periods, stable intertemporal preferences can be written

$$
U=U\left(c_{0} \ldots c_{s} \ldots c_{n}, 0 . n\right) s=0 . \ldots n
$$

${ }^{100}$ See note 97 and accompanying text.

101 This can be illustrated by some specific examples. Suppose as before that the utility that consumers receive at time $t$ from consumption $c_{s}$ at time $s$ is equal to some function $u\left(c_{s}\right)$. However, in contrast to the previous assumptions, suppose that the amount by which consumers prefer present consumption to future consumption, the discount factor $\phi(s, t)$, is a function of $t$, the particular time the decision is made, as well as of $s$, the time when consumption will occur. In general, the discount function $\phi(s, t)$ is assumed to be larger for more remote periods, that is, for large values of $s$. Thus, at any given time $t$, the consumer's utility for $c_{s}$ is $\phi(s, t)$ times $u\left(c_{s}\right)$, or $\phi(s, t) u\left(c_{s}\right)$. His total utility at any time $t$ from consump- 
should be emphasized that the impatient is quite unlike the myope or deliberate, for the time-consistency of preferences is unrelated to the discount rate. An individual with stable preferences who discounts the future at fifty percent per year-whether myopically or deliberately-is nonetheless time-consistent. Conversely, an individual who discounts the future at an almost imperceptible rate, but whose preferences change, has time-inconsistent preferences. ${ }^{102}$

tion in all periods can be written as the sum of his utility from consumption in each future period:

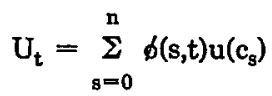

Suppose that the value that subjects place on delayed reward is inversely proportional to delay $s-t$, or in other words, that the discount function takes the form $\phi(s, t)=1 /[(s-t)+k]$ and $\phi u\left(c_{s}\right)=\left(c / s_{s-t+k}\right) u\left(c_{s}\right)$. In this formulation, $k$ is simply a constant, like $R$ in the previous exponential functions. This will be referred to as a proportional discount function. If the discount function is proportional, the individual's utility at any given time $t$ can be characterized by

$$
U=\sum_{s=t}^{n}[1 /(s-t+k)] u\left(c_{s}\right)
$$

The time inconsistency of this can be seen from the following example. Suppose that $k=1$ and $u\left(c_{s}\right)=x^{.5}$ so that

$$
\operatorname{bu}\left(\mathrm{c}_{\mathrm{s}}\right)=\left[(1 /(\mathrm{s}-\mathrm{t}+1)] \mathrm{x}^{\cdot 5}\right.
$$

As before, in period one, the individual is given a choice between receiving $\$ 100$ in period 3 and receiving $\$ 36$ in period 2. At this point he would choose the $\$ 100$.

$$
\begin{gathered}
\text { bu }(100)=\left(100^{5}\right) \div(3-1+1)=3^{1 / 3} \\
\text { कu(36) }=\left(36^{5}\right) \div(2-1+1)=3^{5}
\end{gathered}
$$

The same choice is repeated in period 2. In the second period, however, the individual would rather receive 36 immediately than to wait for $\$ 100$.

$$
\begin{gathered}
\operatorname{\omega u}(100)=100^{5} \div(2-1+1)=5 \\
\phi u(16)=36^{5} \div(1-1+1)=6
\end{gathered}
$$

The reason is that at higher values of $t$, a one-unit change in $t$ produces a smaller change in the discount factor. The proportional difference between $1 / 2$ and $1 / 3$ is less than between $1 / 2$ and 1. The passage of time thus has a disproportionate impact on the utility of proximate events.

Stable, unchanging preferences (i.e. where $\phi=\emptyset(s)$ ) will of course produce time-consistent consumption plans, but one special type of changing preference is also time-consistent. A set of utility functions at various times will produce time-consistent choices if the relative value of consumption at any two points in time is the same regardless of the time at which the comparison is made. This relationship holds for a discount function of the form $R^{s-t}$, where $R$ is any constant. This is sometimes referred to as an exponential discount function, since the delay before $c_{s}$ is consumed, $s-t$, enters into the discount function as an exponent.

${ }^{102}$ Strictly speaking, changing preferences will be inconsistent so long as they are not exponential. For example, a minuscule hyperbolic rate, such as $1 /(1.000001) t$, is still timeinconsistent. 


\section{Empirical evidence.}

There is by now an impressive array of evidence documenting the existence of inconsistency. ${ }^{103}$ The source of this inconsistency is less clearly established. Although it is generally assumed that dynamically inconsistent choice results from preference change, it is possible that inconsistency results from imperfect rationality.

Perhaps the most compelling type of evidence linking time inconsistency to preference change is the phenomenon of precommitment-individuals sometimes deliberately reduce the choices that will be available to them in the future. This can be illustrated by the following example. Suppose that reward B is larger than reward $A$ and would be preferred if the two were offered at the same time. At time 0 , the individual is offered choice $\mathrm{Y}$ between $\mathrm{A}$ at time $t$ and $\mathrm{B}$ at $t+s$. For large values of $t$, the individual prefers $\mathrm{B}$ with a wait of $t+s$ while for smaller values his preferences reverse and he prefers $A$ with a wait of $t$. Now suppose that at time $-k$ ( $k$ periods before time 0 ), the individual is given choice $\mathrm{X}$. Choice $\mathrm{X}$ allows the individual either: (1) access to choice $Y$ after the passage of $k$ periods, at time 0 or (2) reward B at time $k+t+s$. Suppose that with waits of $k+s$ and $k+t+s$ the individual prefers $\mathrm{B}$ to A, but with waits of $t$ and $t+s$ the individual prefers A. To choose alternative (2) has no effect except to foreclose the possibility of choosing $A$ at time 0 . Yet experimental evidence shows that subjects will in fact precommit in this way. ${ }^{104}$ It is difficult to interpret this as anything but strategic behavior to impose self-control. ${ }^{205}$ A perfectly rational subject has no motive to restrict his choices in this way.

\section{Implications for consumer sovereignty.}

If preferences change, and with them the consumer's view of how much he should consume in later periods, then individual sav-

10 Studies using humans include Navarick, 13 Learning and Motivation at 361 (cited in note 8) (negative noise reinforcement with adults); Solnick, et al, 11 Learning and Motivation at 61 (cited in note 8) (same); Millar and Navarick, 15 Learning and Motivation at 61 (cited in note 8); Ainslie and Haendel, The Motives of the Will at 120 (cited in note 8); Benzion, Rapoport, and Yagil, $35 \mathrm{Mgmt}$ Science at 270 (cited in note 8); Thaler, 8 Econ Letters at 201 (cited in note 8). The research on animals is voluminous. Useful surveys can be found in Ainslie, 82 Psych Bull at 463 (cited in note 8); Logue, 11 Behavioral and Brain Sciences at 665 (cited in note 8).

104 See, for example, Rachlin and Green, $17 \mathrm{~J}$ Exprmtl Analysis Behavior at 15-17, 21 22 (cited in note 8 ).

208 Yet it seems unlikely that individuals are wholly strategic. The evidence suggests that pensions and Social Security do not produce the one-to-one offset to savings that would be expected from a wholly rational strategic individual. 
ings decisions will not necessarily maximize welfare. Yet inferring the breakdown of consumer sovereignty from changing preferences is more problematic than it first appears. The first difficulty is that determining the ideal level of savings raises some perplexing philosophical questions. The ideal level of savings should presumably depend in some way on preferences within periods, yet there is no uncontroversial way of making the preferences of various periods commensurable. One solution simply avoids the problem of commensuration by using the most purely neoclassical measure of optimality, Pareto-optimality. Pareto-optimality occurs when no person can be made better off without making any others worse off. ${ }^{106}$ At first glance, the Pareto criteria might seem to have little application to the intertemporal choices of a single individual. However, an individual's set of preferences over time is analogous to the preferences of separate individuals in a single period. ${ }^{107}$ Some economists have modified the Pareto criteria to ask whether utility in one period can be increased without decreasing utility in another period by reallocating consumption between the periods. Using Pareto-optimality to evaluate intertemporal choice raises some difficult technical problems, but suggests that the results of changing intertemporal preferences are sometimes Pareto-optimal, and sometimes not. ${ }^{108}$ Interestingly, nonoptimal levels of savings may as easily be too high as too low. ${ }^{109}$

${ }^{208}$ See, for example, Varian, Intermediate Microeconomics at 305-07 (cited in note 48).

${ }^{107}$ If each period's utility were purely a function of that period's consumption, the Pareto criteria would apply only trivially. Any diminution in a given period's consumption would reduce utility in that period, so no Pareto-improving trades would be possible, and all allocations would be Pareto-optimal. In fact, of course, future consumption does enter present utility, and Pareto-optimality may break down, since the individual may derive the same utility at time $t$ from different allocations of consumption between other periods. For example, the utility function in effect at time $t$ might be indifferent between consumption at time $t$ and at time $t 1$, while utility at time $t 1$ might be improved only by increments to $t 1$ consumption. A marginal addition to $c_{t}$ would therefore be ineffcient. Whether individual choice produces Pareto-optimal consumption depends on a variety of factors such as the strategy employed toward future behavior, whether the past utility or consumption enters current utility, and whether utility for future consumption is anticipatory or altruistic.

${ }^{108} \mathrm{Few}$ models directly consider the problem of a single person with changing preferences, but intergenerational growth models apply by analogy. Models in which such equilibria are not Pareto-optimal can be found in Debraj Ray, Nonpaternalistic Intergenerational Altruism, $41 \mathrm{~J}$ Econ Theory 112 (1987), while models with Pareto-optimal equilibria include John Lane and Tapan Mitra, On Nash Equilibrium Programs of Capital Accumulation Under Altruistic Preferences, 22 Intl Econ Rev 309 (1981) (Pareto-optimal if each generation takes into consideration preceding generation's preferences).

${ }_{108}$ With changing preferences, this can occur because each period is generally assumed to disregard the consumption and preferences of past periods. See, for example, Lane and 
The Pareto criteria is a limited tool, however, because it cannot be used to evaluate the fairness of the distribution between periods. To address the equity of various intertemporal allocations, economists have drawn another analogy to a technique used to analyze welfare issues among different individuals. Specifically, some economists have examined distributional equity through the use of an intrapersonal welfare function, similar to a social welfare function. While the social welfare function balances the utility of separate people, ${ }^{110}$ an intrapersonal welfare function balances the utility functions of a single person over time. ${ }^{111}$ Economists construct the social welfare function to embody various different distributional principles, of which the Rawlsian and the utilitarian are the most prominent.112 This welfare function is not Paretian since it requires comparisons of the utility levels achieved in each period's or person's preference ordering. However, it is methodologically individualist since it respects the preferences of each period or person by preserving the relative valuation of consumption bundles contained in that period's or person's preference orderings. Use of an intrapersonal welfare function does not amount to an endorsement of the kind of paternalism that overrides preferences by, for example, forcing individuals to watch "Masterpiece Theater" rather than "Wheel of Fortune." The evidence of preference change supports the inference that the choices of some individuals are suboptimal. Like the Paretian analysis, the welfare function

Mitra, 22 Intl Econ Rev at 317 (cited in note 108); B. Douglas Bernheim, Intergenerational Altruism, Dynastic Equilibria and Social Welfare, 56 Rev Econ Stud 119, 120 (1989). This assumption of forward orientation has been criticized on philosophical grounds, Parfit, Reasons and Persons at 158-63 (cited in note 97), but for many preference structures, such as exponential ones, the assumption seems embedded in the logic of the function.

110 See, for example, Varian, Intermediate Microeconomics at 529-36 (cited in note 48).

11 Strictly speaking, an intrapersonal welfare function is analogous to the class of social welfare functions that involve a sequence of individuals over time. See, for example, Bezalel Peleg and Menahem E. Yaari, On the Existence of a Consistent Course of Action when Tastes are Changing, 40 Rev Econ Stud 391 (1972).

113 The Rawlsian function represents maximization of the welfare of the least well-off period, Rawls, $A$ Theory of Justice at 152-53 (cited in note 90), and the simple utilitarian provides for maximizing the sum of each period's utility. The weights assigned to each utility function vary according to the distributional principle embodied in the function. The intertemporal intrapersonal welfare function can be written as

$$
\mathrm{U}=\frac{1}{\mathrm{~W}} \sum_{t=0}^{\mathfrak{n}} \mathfrak{u}_{t}^{w}
$$

where $\mathrm{W}$ is some weight. 
suggests that with changing preferences individual choice often fails to produce optimal results. ${ }^{113}$

None of the theoretically plausible welfare analyses support the view that only zero (or at least low) discount rates are rational and that such discount rates may be imputed to all agents. I at least would be willing to respect the preferences of the deliberate individual described earlier, ${ }^{114}$ who has stable, time-consistent preferences but a high discount rate. As the time of lower, later consumption draws near, such an individual will have no regrets about his choices, while the time-inconsistent individual will. ${ }^{115}$ It is therefore difficult to see any advantage gained by altering the choices of a deliberate.

\section{B. Situational Preference Change}

So far I have discussed time-dependent preference changes. However, preferences may change as a function of factors other than time. ${ }^{116}$ Such factors may produce inconsistencies in intertemporal choice that appear to be time-dependent but are not. Between time $t$ and time $t+1$ an individual's preferences between $c_{s}$ and $c_{s+1}$ may reverse not because of the passage of time but because of changes in situational factors. Both types of inconsistency are dynamic, but I will call inconsistencies caused by the passage of time alone "time-dependent," and those resulting from other factors "situational." Situational preference change produces behavior that corresponds to what most of us would call impulsiveness.

113 Suboptimality with preference change results in part from the assumption that each period disregards the consumption and preferences of preceding periods. See, for example, Lane and Mitra, 22 Intl Econ Rev at 309 (cited in note 108); Bernheim, 56 Rev Econ Stud at 119 (cited in note 109).

Note that dynamic inconsistency is not a sufficient condition for the existence of suboptimal behavior. The best Rawlsian and utilitarian plans may not be Pareto-optimal, and may themselves be time-inconsistent, at least under plausible constraints on individual behavior. Partha Dasgupta, On Some Alternative Criteria for Justice Between Generations, 3 J Public Econ 405 (1974); Bernheim, 56 Rev Econ Stud at 123-28 (cited in note 109) (socially optimal plans not time-consistent).

114 See note 102 and accompanying text.

${ }^{118}$ For discussions of the role of regret in justifying paternalism, see Kelman, 1979 Wis L Rev at 778-87 (cited in note 39); Anthony Kronman, Paternalism and the Law of Contracts, 92 Yale L J 763 (1983). Regret seems to be a necessary but not a sufficient requirement for paternalistic intervention. If preferences change, then optimal current consumption from the perspective of any given period will generally be higher than what would be dictated by the point.

${ }^{118}$ The utility function may be written to be dependent on these parameters $x$. In other words, it may be written as

$$
U_{t}=U\left(c_{0} \ldots c_{s} \ldots c_{n}, 0 \ldots s \ldots n, x\right) s=0 \ldots n
$$


The best evidence of situational preference change is found in the experiments of the social psychologist Mischel and others, which have shown that self-control is facilitated by circumstances that make it easy for the individual to keep his mind off temptation. ${ }^{117}$ In many of these experiments, subjects are given a choice between a less preferred treat (say, gumdrops) now and a more preferred treat (say, chocolate) later. It should surprise no one to learn that a subject's attempt to delay is hindered if the gumdrops, which he is permitted to eat now, are placed in front of him. Interestingly, though, he is more likely to eat the gumdrops now if the chocolate, which he is not permitted to consume, is placed in front of him instead. ${ }^{118}$ In other words, thinking about the rewards of delaying gratification reduces rather than increases self-control. If preferences were purely a function of temporal distance, this should not occur. Purely time-dependent models of preference change imply that, given a choice between gumdrops at time $t$ and chocolate at $t+1$, people will choose chocolate at large values of $t$ and gumdrops at smaller values. The physical presence of the unavailable chocolate should have no effect on the decision to consume the gumdrop now. If factors other than time, such as reminders of a future reward, produce inconsistency, then that inconsistency must result from a situational preference change. ${ }^{119}$ This situation-dependent change explains the behavior of the impulsive, ${ }^{120}$ who spends his paycheck when faced with temptation, and quickly regrets his improvidence.

By identifying situational forces that cause inconsistent choice, psychologists have distinguished the inconsistency of the impulsive empirically from that of the impatient. Yet impatients and impulsives share traits that distinguish them both from deliberates. There is the obvious fact of inconsistency. Moreover, as with time-dependent preference change, the existence of precommitments indicates the presence of situational preference change. For example, for many years bank Christmas Clubs required con-

117 Mischel, Ebbesen, and Zeiss, $21 \mathrm{~J}$ Personality and Soc Psych at 204 (cited in note 8). 118 Id.

110 Loewenstein has explored a fascinating variation on this phenomenon in a study that found that the willingness of subjects to defer consumption varied tremendously, depending on how the deferral decision was framed. Especially important was whether the decision was framed as a delay of something presently owned or as the expedited receipt of a future interest. Loewenstein, $34 \mathrm{Mgmt}$ Sci at 200 (cited in note 8). See also Loewenstein, 97 Econ $J$ at 666 (cited in note 8). Situational preference change probably underlies the problem of self-control as discussed by Thomas Schelling in his famous essay, The Intimate Contest for Self-Command, in Schelling, Choice and Consequences at 57 (cited in note 8). 130 See text accompanying notes 117-19 for a description of the impulsive. 
sumers to deposit money weekly in a bank account that paid no interest, and from which funds could not be withdrawn until late November. The drug Antabuse, which makes the user nauseated if he subsequently consumes alcohol, is voluntarily taken by alcoholics to deter their own future consumption of alcohol. Both Christmas Clubs and Antabuse are precommitment devices. If preferences were independent of situational forces, individuals would simply abstain from pre-Christmas spending or from alcohol. But there is a subtle difference between Antabuse and Christmas Clubs, the precommitments of impulsives, and the precommitments of impatients. The self-imposed limits of the impulsive protect him from particular temptations at indeterminate future times, while those of the impatient guard against increased temptation that results solely from an increase in temporal proximity.

In some important ways, though, an impatient has more in common with a deliberate than either does with an impulsive. Most importantly, the behavior of impatients conforms to the fundamental neoclassical principle of marginalism, ${ }^{121}$ while the behavior of impulsives does not. This feature of situational preference change may explain some puzzling facts about savings behavior. Suppose that two individuals, A and B, each have the same tastes and each has a net worth of $\$ 100$. The principle of marginalism states that both should choose consumption levels that equate marginal utility in the present period with marginal utility in future periods.

Since both have the same level of wealth and the same tastes, both should generally choose the same consumption levels. A qualification to the principle of marginalism occurs if some wealth is held in illiquid form. For example, suppose that both individuals wish to consume $\$ 70$ today. However, suppose that A's wealth is all in liquid assets such as cash, while B's is allocated half to cash and half to illiquid assets. A will be able to consume $\$ 70$ today, since his wealth is liquid. B, however, will not. The principle of marginalism acknowledges that marginal utility between periods may not be equated if some impediment (like illiquidity) interferes. But that illiquidity can only interfere if it is on the margin, that is, if it directly prevents consumption of the optimal marginal level. Suppose that both A and B wish to consume $\$ 40$ today. Under the previous assumption that A's wealth is all liquid, while B's is half liquid, both have liquid assets adequate to finance their

121 For an explanation of marginalism, see note 40 and accompanying text. 
desired level of consumption, so both should consume $\$ 40$. Nonmarginal illiquidity-that is, illiquidity that does not directly obstruct the marginal decision-should not affect consumption choices. $^{\text {.22 }}$

Yet in practice it seems to do so: the marginal propensity to consume (MPC) seems strongly positively correlated to non-marginal liquidity as well as to wealth. ${ }^{123}$ Under the previous assumption that $\mathrm{A}$ has more liquidity than $\mathrm{B}, \mathrm{A}$ will usually spend more than $B$ in the current period. To some extent this correlation may result from taste differences. Consumers with low MPCs may be more willing than consumers with high MPCs to lock assets away in illiquid form. Likewise, taste differences may contribute to the marginal propensity to consume housing wealth, ${ }^{124}$ since housing is endogenous, or chosen by the individual. But non-marginal illiquid assets, such as Social Security and to a lesser extent private pensions, whose levels are exogenously set, also exert the same mysterious effect on spending. ${ }^{125}$ These observations are hard to reconcile with deliberate or even impatient behavior, but make perfect sense if people are impulsive. The availability of non-marginal wealth is a situational factor, like the proximity of chocolate, that affects behavior. Impulsive behavior may explain some of the poor performance of the neoclassical savings model in econometric stud-

122 Hersh M. Shefrin and Richard H. Thaler, The Behavioral Life-Cycle Hypothesis, 26 Econ Inquiry 609, 615 (1988).

${ }^{123}$ For excellent surveys of these issues, see id at 609; Richard H. Thaler, Saving, Fungibility, and Mental Accounts, $4 \mathrm{~J}$ Econ Persp 193 (1990).

126 See Jonathan Skinner, Housing Wealth and Aggregate Saving, 19 Regional Sci and Urban Econ 305 (1989); Joyce M. Manchester and James M. Porterba, Second Mortgages and Household Saving, 19 Regional Sci and Urban Econ 325 (1989).

${ }^{123}$ Standard theory predicts that in a regression of total savings on various variables, the coefficient on Social Security and pensions should be -1 . Most studies found coefficients that were negative and significant but did not approach -1 . Lawrence J. Kotlikoff, Testing the Life Cycle Theory of Social Security and Life Cycle Accumulation, 69 Am Econ Rev 396, 404 (1979) (-.666 for Social Security in savings equation with cross-section data); Phillip Cagan, The Effects of Pension Plans on Aggregate Saving: Evidence from a Sample Survey, National Bureau of Economic Research, Occasional Paper 95 (National Bureau of Economic Research, 1965); George Katona, Private Pensions and Individual Savings (Michigan, 1965); Alan S. Blinder, Roger H. Gordon, and Donald E. Wise, Social Security, Bequests and the Life Cycle Theory of Savings: Cross-Sectional Tests, in Franco Modigliani and Richard Hemming, eds, The Determinants of National Saving and Wealth 89, 114 (cross-sectional data; coefficient on pensions has wrong sign, on Social Security -.39, and neither significant); Robert J. Barro, The Impact of Social Security on Private Saving 2136 (American Enterprise Institute, 1978). But see Martin Feldstein and Anthony Pellechio, Social Security and Household Wealth Accumulation: New Microeconometric Evidence, 61 Rev Econ \& Stat 361 (1979) (coefficients in cross-sectional savings equation between -.57 and -1.67 . 
ies. ${ }^{128}$ As we will see in the next section, the breakdown of marginalism is of great interest to pension policy-makers.

More generally, impulsiveness presents more puzzles for neoclassical welfare theory than impatience does. While time-dependent preference change can be described easily using only the neoclassical building blocks, ${ }^{127}$ particularly individual choices, situational factors are not in the neoclassical's usual bag of economic tricks. Consequently, describing the changes these factors produce is not straightforward. ${ }^{128}$ The welfare analysis of impulsiveness is similarly more problematic than that of impatience. The Paretian and welfare function approaches to analyzing time-dependent preference change depend on preferences that are determinate enough to allow comparisons among different situations. Situational preference change implies that preferences are so sensitive to circumstances that it is difficult to compare an individual's valuations when circumstances change. If preferences are as indeterminate as this, economists cannot easily base welfare analysis on individual choices, and no one has yet suggested any comparably precise, theoretically appealing alternative. Any argument that a given savings level is or is not optimal must ultimately appeal to intuitions, such

${ }^{128}$ See Blinder, Gordon, and Wise, Social Security, Bequests and the Life Cycle Theory of Savings: Cross-Sectional Tests at 113-15 (cited in note 125).

${ }^{127}$ Indeed, many such models exist. See Ray, $41 \mathrm{~J}$ Econ Theory at 112 (cited in note 108); Lane and Mitra, 22 Intl Econ Rev at 309 (cited in note 108); Bernheim, 56 Rev Econ Stud at 119 (cited in note 109); Peleg and Yaari, 40 Rev Econ Stud at 391 (cited in note 111); Dasgupta, 3 J Public Econ at 405 (cited in note 113).

${ }^{228}$ Situational factors such as proximity of the desired object might be inserted into the utility function as a parameter $x$, so that utility would be written:

$$
U_{t}=U\left(c_{0} \ldots c_{s} \ldots c_{n}, 0 \ldots s \ldots n, x\right) s=0 . \ldots n
$$

However, incorporating these situational factors is obviously incompatible with the fundamental simplification of neoclassical theory, the restriction to two primitives, choices and preferences, and one observable, choices. Enlarging the scope of economic theory in this way produces two problems. The rationale for restricting admissible evidence to choices was to rule out data that was unreliable, or difficult to quantify. Unless the situational variables $x$ can be uncontroversially observed and measured they are simply a deus ex machina. A quantified social science requires some stylization of the determinants of behavior, and there is at present no way of summarizing and aggregating the various factors that Mischel identifies as relevant. For example, one of the situational variables might be referred to as proximateness. Which is more proximate, a chocolate the subject can see or one he can smell? The answers to such questions cannot be the data of investigation but are rather subjects of investigation in themselves. Moreover, even if a general quantified theory of the factors underlying, say, proximateness were available, and could be incorporated into a utility function, the resulting framework might be a valuable tool for experimental psychology, but it would not be terribly useful in the study of market behavior, since it is impossible to know all the circumstances surrounding each market choice. Indeed, the need to stylize data was one of the original motivations for restricting the class of primitives to choices. 
as that about the low likelihood that steeply declining lifetime consumption maximizes utility.

\section{Paternalistic Pension Policies for Impulsives and IMPATIENTS}

As we have seen, there are troubling distributional flaws in our present pension policy: the present system of retirement income security provides the largest subsidies to affluent households that would save without help, and leaves uncovered a significant part of the population, many of whom suffer declines in income during retirement. ${ }^{129}$ This coverage pattern results from relying on a private pension system that is not mandatory in the sense that the provision of pensions by employers is voluntary. Consequently, coverage is far from universal: individuals who work for firms without pension plans, generally small ones, cannot be covered, and thus cannot receive the tax subsidy. ${ }^{130}$

All of the alternatives proposed to date have serious problems. Mandatory employer-sponsored plans might remedy the current gaps in coverage, but small firms seem likely to be inefficient providers of what is a fairly sophisticated financial service. Other mandatory schemes are politically infeasible. ${ }^{131}$ Congress has good reason to be reluctant to shift to a system of incentives from the present reliance on Social Security and employer-sponsored pensions. Non-employer schemes currently under consideration rely too heavily on individual choice. These incentive-based plans, like the Bush and Bentsen proposals, which essentially amount to IRAs, are simply not well-designed to improve the situation of the most impulsive or impatient consumers. ${ }^{132}$

Congress thus needs new proposals. This section will examine some possible ways, founded on the empirical evidence I have explored, to incorporate paternalistic concerns without relying on Social Security or employer oversight. It should be emphasized that the empirical analysis of preference change is still quite tentative, and it is premature to attempt to predict too precisely the effect of

\footnotetext{
120 See notes 31-38 and accompanying text.

230 Ippolito, Pensions, Economics and Public Policy at $189-90$ (cited in note 4).

131 Graetz, $135 \mathrm{U} \mathrm{Pa} \mathrm{L}$ Rev at 907 (cited in note 4).

132 See notes $133-49$ and accompanying text.
} 
any particular policy. However, the existence of preference change suggests some general policy directions.

A. Incentive Plans

1. Situational preference change.

Incentive-based schemes to increase savings run the gamut from a pure, unrestricted capital subsidy such as a capital gains cut, to more narrowly tailored subsidies like IRAs, to heavily regulated employer pensions. Congress has been skeptical about proposals to shift from the present system favoring the more regulated pension assets to a system with increased individual choice and pure tax subsidies. ${ }^{133}$ The evidence of situational preference change suggests that this skepticism may be justified, and that pure tax subsidies would be ineffective. The abstract future benefits of a higher return on savings may seem slight at a time when immediate temptation is great. A typical impulsive is an individual to whom a good meal seems more appealing on Friday, when his pay is received, but to whom future security seems more important on Monday. It seems unlikely that an increase in the rate of return from, say, ten to fifteen percent would influence such an individual's Friday behavior, and by Monday it is too late.

Capital subsidies, the standard neoclassical means of increasing savings, are thus ineffective in dealing with an impulsive. But the behavior of an impulsive individual can be manipulated with two policy tools that will not affect a person with stable preferences: precommitments and "distraction techniques." Both precommitments and distraction techniques in principle should work without a subsidy, but a mixed policy that combined either with a subsidy might be especially effective.

The simplest of the two is a distraction device. The key lesson of Mischel's work is that factors that focus attention on the possibility of gratification, whether present or delayed, tend to reduce self-control. ${ }^{134}$ For example, thinking about eating reduces the ability to forego a less desirable food now in return for a more desirable one later. ${ }^{135}$ An example of a distraction technique to encourage saving is a payroll withholding plan that would allow employees to elect to have their employers deduct a certain amount from their paycheck every week and deposit it in a savings account. Such plans might even leave the individual perfectly free to

138 Many such proposals have been introduced, see notes 58-62 and accompanying text, but none enacted.

2as See notes $117-20$ and accompanying text.

135 Id. 
terminate his participation or withdraw from the account at any time. Yet the automatic nature of the withholding would tend to discourage current consumption. An individual who must actually force himself each week to divide his paycheck between his checking account and his savings account resembles a child who must look at the candy bar he wants. An automatic withholding plan works in the same way as hiding the candy.

In principle, savings should rise when distraction mechanisms are readily available, even in the absence of any subsidy or other incentive to save. A mere payroll withholding option would probably induce at least some individuals to save more. In practice, many employers and banks offer such schemes through direct deposit arrangements. But such withholding arrangements are not available to all consumers-and even when they are available, implementing them at present involves initiative and planning. Instead, Congress could institutionalize a withholding arrangement by incorporating it into the tax withholding system. Individuals could choose direct savings withholding by simply filling in one more number on a W-4 form. The employer could direct funds where the individual specified or into a Treasury Direct account. This would to some extent mimic the common practice of deliberately overwithholding in order to receive a refund, a habit to which I reluctantly confess.

Withholding policies might be even more effective if combined with a subsidy. But none of the present pension subsidies makes systematic use of people's willingness to engage in distraction techniques. IRAs permit homemade self-control devices: individuals are permitted to make deposits to IRA accounts over the course of the year, ${ }^{136}$ and many employers and banks permit direct payroll deposits, which employees can allocate between accounts. ${ }^{137}$ But the IRA direct-deposit arrangement takes initiative and organization, and is not a precondition of the IRA tax subsidy. In practice, many CODAs employ withholding arrangements, although the Code does not require or encourage employers to offer withholding. Indeed, the prevalence of withholding arrangements may contribute to Congress's preference for CODAs over IRAs. ${ }^{188}$ But CODAs have one substantial disadvantage: employers are not required to provide them, and some people are self-employed, so not all work-

\footnotetext{
${ }^{138}$ Nothing in the Code speaks to this point but a phone call to any bank will confirm that such arrangements are easily made.

${ }^{137}$ See note 20 and accompanying text.

13s See notes 20-24 and accompanying text.
} 
ers can take advantage of them. Congress could better obtain the advantages of withholding by equalizing the subsidy to various pension assets and facilitating withholding arrangements for IRAs through payroll or tax withholding mechanisms. Indeed, even the distributive problem with IRAs-that they serve primarily the affluent-might diminish if withholding mechanisms made IRA participation easier. An impressive body of evidence suggests that the impulsiveness that withholding methods cure is more prevalent among the less affluent. ${ }^{139}$

Besides distraction techniques, a second potential set of remedies for impulsiveness includes measures designed to encourage precommitment against withdrawal. Specifically, legislators might encourage individuals not only to withhold from their pay, but to lock up their wealth in assets from which withdrawal was prohibited, penalized, or merely difficult. Precommitment mechanisms, like distraction techniques, should work in principle without a subsidy, but precommitment, even more than distraction, makes better sense as part of a subsidy plan. A belief in the value of precommitments may in part explain Congress's preference for noncontributory employer plans over CODAs, and for either over IRAs. ${ }^{140}$ But there is in principle no connection between the illiquidity of a retirement asset and whether it is employer sponsored. At present, IRAs are subject only to a withdrawal penalty, ${ }^{141}$ but a number of other obstacles could be placed in the way of IRA withdrawals. Congress could virtually prohibit withdrawals, as it does for noncontributory employer plans. ${ }^{142}$ As with CODAs, withdrawals might be subject to a hardship requirement, ${ }^{143}$ whereby individuals would have to make a formal application to the financial institution's plan administrator. Even if generally granted, this added obstacle should discourage impulsive withdrawals of funds. Finally, Congress might require advance notification of an intention to withdraw.

The effectiveness of devices to discourage liquidity illustrates the generally diminished relevance of marginalism to individuals with situational preference change. A corollary is that the usual economic arguments against tax ceilings do not apply to impulsive

130 Further, the ideal subsidy would probably be progressive, that is, would be higher for those in lower income groups. Weiss, Welfare for the Rich \$ III. A. (cited in note 70).

${ }^{140}$ See notes 19-20 and accompanying text.

141 IRC \& 72(t).

142 See note 26 and accompanying text.

${ }^{143}$ IRC \& 401(k)(2)(B)(i). 
individuals. Impulsives may replace amounts shifted into IRAs by other liquid assets to a greater extent than deliberates.

A combined scheme of subsidies, precommitments, and distraction devices could take many forms, but it is difficult to discern the ideal structure of tax incentives from the existing experimental evidence. The conventional implementation of a subsidy conditioned on a precommitment would require an irrevocable decision to withhold at the beginning of the tax year, followed by a tax deduction on that year's return. Alternatively, an individual who agreed to the automatic withholding of $\$ 50$ a week from his paychecks for the next year might receive an immediate tax credit of equal present value, instead of a later deduction. One potential drawback of the conventional approach is that the reward is too far delayed to affect behavior. On the other hand, Mischel's results suggest that focusing on the reward for waiting may be as detrimental to self-control as focusing on immediate gratification. The matter is complicated further by the fact that cool, non-arousing reminders of reward increase self-control, while arousing reminders decrease it. ${ }^{144}$ Without further evidence it is difficult to speculate on the timing arrangement that would maximize self-control.

2. Time-dependent preference change.

An impatient individual with time-dependent preference change is more like a neoclassical consumer than an impulsive individual, and legislators must use different tools to alter the savings of impatients than to alter the savings of impulsives. Since the impatient's preferences are stable, and are thus immune to situational factors, impatients respond in predictable ways to incentive changes. Tax subsidies that are ineffective with impulsives can be used to increase the impatient's savings. Second, impatients, like rationals, ignore non-marginal illiquidity. ${ }^{145}$ The impatient allocates resources so that the marginal costs and marginal benefits are equated within the period. Policies that exploit the effect of non-marginal liquidity on impulsive behavior will not work on impatients. A subsidy with a ceiling below the marginal level will not increase savings, and distraction techniques will not deceive the impatient into ignoring non-marginal wealth.

But legislators can manipulate the behavior of both impatients and impulsives with precommitment mechanisms, which will not affect the behavior of rationals. To be effective, though, precom- 
mitment mechanisms probably require a longer time horizon for impatients than for impulsives. The impulsive wants to protect himself from a relatively short, recurring cycle of binging and regret, like spending every Friday's paycheck and regretting that splurge every Monday. In contrast, the time-dependent preference change of the impatient occurs over the course of his lifetime, and evolves at a gradual rate. The effectiveness of precommitment devices increases as the time at which the commitment must be met is pushed further into the future. An impatient finds deferring consumption from tomorrow to the next day easier than deferring consumption from today to tomorrow, but finds it easier still to defer consumption from a day in five years to five years and a day. This lengthy time horizon indicates that a policy of directly encouraging long-term savings commitments may not be feasible. It is difficult to envision individuals entering into a long-term agreement to permit tax withholding over a course of many years, especially given each individual's uncertainty as to his future consumption needs.

Perhaps, though, the desirability of long-term precommitments provides a partial justification for the home mortgage deduction, ${ }^{146}$ the most maligned personal tax preference. ${ }^{147} \mathrm{~A}$ mortgage is a kind of precommitment device in which the mortgagee promises to make a series of payments over a long term. In addition, investment in housing seems to exploit situational factors as well, since the present enjoyment of a home may make housing a relatively painless form of savings for most impulsives. ${ }^{148}$ of course, the current housing deduction is not ideally designed: an equity deduction would encourage savings more effectively than the present interest deduction. ${ }^{149}$

\section{Protection from creditors.}

If individuals behave as rational economic agents, the special protection from creditors accorded to retirement assets ${ }^{150}$ is diff-

${ }^{146}$ IRC $\S \S 163(a), 163(h)(1)-163(h)(3)$.

${ }^{147}$ See, for example, Stephen R. Munzer, $A$ Theory of Retroactive Legislation, 61 Tex L Rev 425, 452-56 (1982).

${ }^{148}$ Some might argue that housing is not a form of savings for these purposes, since it does not provide a flow of cash. But the imputed rental services of a fully paid house reduces the homeowner's cash needs, and in any event a house can always be sold for cash.

149 Payments on a mortgage can be broken down into two components: interest and reduction of principal. Reduction of principal, or increases to equity, are in effect a form of savings, since they increase the debtor's net worth. But interest payments are not a form of savings since they leave the principal amount unaffected. The present deduction, IRC $\S \S 163(\mathrm{a}), 163(\mathrm{~h})(1)-163(\mathrm{~h})(3)$, applies only to interest, yet allowing a deduction for reductions of principal makes more sense if the congressional objective is to encourage savings.

${ }^{180}$ See notes $28-29$ and accompanying text. 
cult to justify. Such protection creates moral hazard problems, especially with respect to pension assets which the debtor controls. ${ }^{181}$ However, changing preferences seem to provide a general justification for restrictions on the alienability of pension wealth. ${ }^{152} \mathrm{Al}-$ though preference change does not necessarily eliminate moral hazard concerns, it suggests that legislators should address moral hazard issues with narrowly tailored tools, in order to accommodate paternalistic concerns. In this light, the distinction between pension assets which individuals control and those which they do not control seems overly broad, since bankruptcy law contains numerous more finely-tuned protections against fraudulent conveyances. ${ }^{153}$

\section{B. Mandatory Savings Plans}

Though it is too early to know which of the two is more important, there is evidence for the existence of both time-dependent and situational preference change. Yet our understanding of each phenomenon is nowhere near the point where the exact effects of any given subsidy level or precommitment policy can be even roughly estimated. Perhaps more importantly, the actual workplace is likely to contain a mixture of impatients, impulsives, and deliberates. An incentive-based plan will have different effects on each of these groups. Unlike incentive programs, a mandatory savings plan will increase savings in a predictable way, regardless of why or how much preferences change, ${ }^{164}$ and deserves serious consideration. A surprisingly high number of observers take seriously the possibility of a mandatory plan as a substitute either for Social

\footnotetext{
${ }^{281}$ See notes 67-68 and accompanying text.

${ }^{162}$ This has been pointed out by Thomas H. Jackson, The Logic and Limits of Bankruptcy Law 232-43 (Harvard, 1986).

${ }^{163}$ See, for example, 11 USC \& 548. Jackson supports the bankruptcy exemption for a broad range of pension assets, including Keogh plans. Jackson, The Logic and Limits of Bankruptcy Law at 262-64 (cited in note 152). His argument seems to depend more on his collective action theory of bankruptcy law than on his paternalistic justification of the policy of discharge. Since Keogh plans cannot be reached by creditors individually, he suggests, there is no collective action problem and therefore no reason to include these assets in the estate. Id at 261 . He does not address the more general question of whether the non-bankruptcy protection from individual creditors is justified.

${ }^{264}$ If consumers are strategic, though, it may not be sufficient to require savings in the difference between the amount the individual would have saved and the amount he ought to save. Strategic consumers may offset marginal increments to savings by reducing the voluntary component of savings.
} 
Security or for voluntary employer sponsored pensions. ${ }^{155}$ The key point of contention with respect to such a plan is whether it should be implemented through employers, ${ }^{156}$ through government, ${ }^{157}$ or through private financial intermediaries. ${ }^{158}$ Each of these alternatives has problems. Reliance on employer plans is problematic because not all employers are well situated to make long-term contracts and complex financial decisions. Even those skeptical of the power of the market may be dismayed by a government-run plan with a budget of over a trillion dollars, the magnitude of the present private pension system. But the proposed plans that would make use of private financial intermediaries seem based on strong assumptions about the reliability of individual choice, and view increasing choice as an unalloyed good. ${ }^{159}$ The problems associated with financial intermediaries seem to be the most tractable. There is no reason why financial intermediaries cannot assume a paternalistic role as well as employers. To the extent that concerns about individual choice center on investment decisions, the same fiduciary requirements, funding rules, and insurance programs that ERISA imposes on employers could be imposed on financial institutions. ${ }^{160}$ To the extent that employers supervise such matters as hardship withdrawals, a financial intermediary could provide the benefits of supervised illiquidity just as easily.

\section{ConcLusion}

The current system of retirement income security favors Social Security and non-contributory employer pensions, two arrangements that do not rely heavily on individual choice. This implicit paternalism is difficult to justify using neoclassical consumer theory, long the main tool of analysis in savings policy. But lawmakers have been reluctant to adopt more choice-oriented arrangements. Evidence from psychologists confirms their suspicion that individuals may not always make long-term decisions in their own best interest.

165 President's Commission on Pension Policy, Coming of Age 'at 41-44 (cited in note 85); Bankman, $55 \mathrm{U}$ Chi L Rev at 825-26 (cited in note 36); Wolk, $70 \mathrm{Va}$ L Rev at 466-67 (cited in note 68). 85).

${ }^{186}$ President's Commission on Pension Policy, Coming of Age at $41-44$ (cited in note

${ }^{167}$ Paul Starr, Social Security and the American Public Household, in Theodore R. Marmor and Jerry L. Mashaw, Social Security: Beyond the Rhetoric of Crisis 119, 143-48 (Princeton, 1988).

188 Ippolito, Pensions, Economics and Public Policy at 210 (cited in note 4).

189 Id at 207-27.

160 ERISA §§ 301-308 (funding); §§ 401-414 (fiduciary); §§ 4001-4009 (insurance). 
The present system of pensions and Social Security advances paternalistic aims in a haphazard way. To the extent that Congress wishes to rely on incentives, it could broaden the tax preference by imposing a uniform ceiling on the total of all subsidized assets while incorporating paternalistic concerns through IRA reform. To the extent that either private pensions or Social Security are replaced by a mandatory system, there is no need to rely either on the government or on private employers to further paternalistic goals. Congress can rely on financial intermediaries to obtain the advantages of specialization and competition without impeding either its ability to impose paternalistic restrictions on individual conduct or its ability to regulate the behavior of the financial intermediaries.

Of course, even if paternalistic policy could incontrovertibly improve individual welfare, some would object on the grounds that the right of autonomous individuals to make their own mistakes is an end in itself. Though this argument has, in my view, some force, it does not seem a sufficient basis for rejecting all varieties of paternalism. In the words of one of the great neoclassicals,

[t] he paternalistic ground for governmental activity is in many ways the most troublesome to a liberal; for it involves the acceptance of a principle-that some shall decide for others-which he finds objectionable in most applications and which he rightly regards as a hallmark of his chief intellectual opponents .... Yet there is no use pretending that problems are simpler than in fact they are. There is no avoiding the need for some measure of paternalism. . . . There is no formula that can tell us where to stop. We must rely on our fallible judgment and, having reached a judgment, on our ability to persuade our fellow men that it is a correct judgment, or their ability to persuade us to modify our views. ${ }^{161}$

102 Milton Friedman, Capitalism and Freedom 33-34 (Chicago, 1962). It must be added, though, that Professor Friedman strenuously objects to paternalistic savings policy. Id at $189-90$. 
